\title{
THE BAIKAL RIFT: Pliocene (MIOCENE) - QUATERNARY EPISODE OR PRODUCT OF EXTENDED DEVELOPMENT SINCE THE LATE CRETACEOUS UNDER VARIOUS TECTONIC FACTORS. A REVIEW
}

\author{
V. D. Mats
}

\section{13/10 Shaar Hagai, Karmiel, Israel}

\begin{abstract}
The article reviews three typical concepts concerning the age of the Baikal rift (BR) which development is still underway: $5 \mathrm{Ma}$ (the BR development start in the Late Pliocene), $30 \mathrm{Ma}$ (Miocene or Oligocene), and 60-70 Ma (the Late Cretaceous).

Under the concept of the young BR age (Pliocene-Quaternary) [Artyushkov, 1993; Nikolaev et al., 1985; Buslov, 2012], according to E.V. Artyushkov, BR is not a rift, but a graben due to the fact that the pre-Pliocene structure of BR does not contain any elements that would be indicative of tensile stresses. However, field studies reported in [Lamakin, 1968; Ufimtsev, 1993; Zonenshain et al., 1995; Mats, 1993, 2012; Mats et al., 2001] have revealed that extension structures, such as tilted blocks and listric faults, are abundant in the Baikal basin (BB), and thus do not support E.V. Artyushkov's argumentation.

The opinion that BR is young is shared by M.M. Buslov [2012]; he refers to studies of Central Asia and states that only the Pliocene-Quaternary structure of BB is a rift, while the oldest Cenozoic structures (Upper Cretaceous Miocene) are just fragments of the large Cenozoic Predbaikalsky submontane trough (PBT) which are not related to the rift. However, the coeval Cenozoic lithological compositions, thicknesses of sediment layers and types of tectonic structures in PBT and BB have nothing in common. Across the area separating PBT and BB, there are no sediments or structures to justify a concept that BR and PBT may be viewed as composing a single region with uniform structures and formations. The idea of the Pliocene-Quaternary age of BR should be rejected as it contradicts with the latest geological and geophysical data. Seismic profiling in BB has revealed the syn-rift sedimentary bed which thickness exceeds $7.5 \mathrm{~km}$. Results of drilling through the 600-metre sedimentary sequence of Lake Baikal suggest the age of $8.4 \mathrm{Ma}$ [Horiuchi et al., 2004], but M.M. Buslov believes that it took only about 5 Ma to form the entire syn-rift sequence of Lake Baikal.
\end{abstract}

In [Bazarov, 1986; Rasskazov et al., 2014; Mashchuk, Akulov, 2012; Hutchinson et al., 1993; Zonenshain et al., 1995; Kaz'min et al., 1995], the BR age is determined as the Miocene (Oligocene-Miocene) according to the age of the Tankhoi suite (Miocene or Oligocene-Miocene) and the correlation between the lower seismostratigraphic complex (SSC-1) and the Tankhoi suite [Hutchinson et al., 1993; Zonenshain et al., 1995]. The Tankhoi suite lies directly on the crystalline basement of the rift and is believed to mark the start of the Baikal syn-rift profile. However, this concept does not take into account the main specific feature of the profile, i.e. a developing rift. As shown in Fig. 6, the most ancient elements in the syn-rift profile are inside the deep part of the rift. At the day surface, the basement is overlaid by the younger elements of the sedimentary wedge due to the 'expansion non-conformity effect' (as termed in [Khain, Mikhailov, 1985]). In our opinion, it is incorrect to correlate SSC-1 and the Tankhoi suires - the representative seismic profile (Fig. 5) shows that SSC-1 falls out of the profile before reaching the day surface and leans against the rising slope of the basement, while SSC- 2 correlates with the Tankhoi suite. Besides, correlating SSC-1 with the Tankhoi suite is contradicting to the data of structural studies reported in [San'kov et al., 1997; Delvaux et al., 1997]. SSC-1 originated before the time when the Lake Baikal region was impacted by the Indo-Eurasian collision and formed under the influence of pure expansion when tensile stresses were oriented from NW to SE across the strike of the rift along the SE $145-150^{\circ}$ azimuth [Zonenshain et al., 1995]. By the time of the SSC-2 formation, the stress vector turned counterclockwise towards the NE-SW direction at an acute angle to the rift strike. The Baikal rift structure was changed as the single-sided basin was replaced by the SW-NE stretching dual-sided graben; it included SSC-2 and was bordered by listric faults [Zonenshain et al., 1995].

Results of the structural studies conducted on the Lake Baikal shores [San'kov et al., 1997; Delvaux et al., 1997; Parfeevets, San'kov, 2006] suggest that during the Tankhoi period, the rift developed in conditions of transpression and transtension under the influence of stresses oriented subparallel to the strike of the rift and related to the IndoEurasian collision. This means that SSC-2 (but not SSC-1) correlates with the Tankhoi suite, and the age of the Tankhoi suite is not indicative of the BR age, and the concept of the Miocene (Oligocene-Miocene) age of BR is thus discarded.

The concept of the Late Cretaceous-Paleogenic age of BR [Logachev, 1974, 2003; Mats, 1987, 1993, 2012; Mats et al., 2001; Mats, Perepelova, 2011] is most fully supported by the available geological and geophysical data. This age is evi- 
denced by the Paleogenic (Eocene) palinspectra detected in core samples from deep wells drilled in the Selenga river delta, Southern Baikal basin [Faizulina, Kozlova, 1966]. Besides, the Paleocene-Eocene pre-Tankhoi sediments are discovered at the Khamar-Daban shore of the Southern Baikal basin (the Polovinka river valley) [Mats, 2013]. The sediments of the BB weathering crust [Mats, 2013] correlate with the paleontologically dated Paleogenic sediments of PBT [Pavlov et al., 1976; Popova, 1981]. The BR ancient age is also confirmed by studies reported in [Nikolaev, 1989; Galazii et al., 1999; Kontorovich et al., 2007; Jolivet et al., 2009].

Our review of the BR age concepts gives grounds to conclude that the Pliocene-Quaternary and Oligocene-Miocene ("Tankhoi") ages of BR should be discarded as not supported by the geological and geophysical data collected in the recent studies.

Based on the comprehensive studies of the Baikal rift and taking into account an extension of the BR evolution by 60 to $70 \mathrm{Ma}$, we propose a new concept of the BR development and introduce a three-stage model (Fig. 7) (as a replacement of the well-known two-stage model [Logachev, 2003]) and an impactogenic model as a supplement to the passive and active rifting models [Mats, 2012; Mats, Perepelova, 2011].

In our model, the first stage of the BR development is the Late Cretaceous-Early Oligocene (70-30 Ma): in conditions of the general extension of the lithosphere, BR forms as a slot-type (the term proposed by E.E. Milanovsky) rift and develops, as shown by the passive rifting model, at the background of the original peneplain until the time when the Baikal region is impacted by stresses resulting from the Indo-Eurasian collision; the rift structure is a single-sided basin that comprises the seismically transparent seismostratigraphic complex (SSC-1); it is bordered at NW by the zone of listric faults.

The second stage is the Late Oligocene-Early Pliocene (30-5 Ma): BR develops under the impact of stresses resulting from the Indo-Eurasian collision; the dual-sided graben is formed; it comprises SSC-2 that is stratified and deformed.

The third stage is the Late Pliocene - Quarter (5 Ma till present): BR develops under the impact of stresses generated by local deep sources, as shown by the active rifting model [Logachev, Zorin, 1987; Zorin et al., 2003]; another single-sided graben is formed; it is bordered by listric faults from the NW and comprises SSC-3 that is stratified but not deformed.

Key words: Baikal rift; age; Late Cretaceous - present; three-stage formation model; active, passive and impact-genic rifting models

Recommended by E.V. Sklyarov

For citation: Mats V.D. 2015. The Baikal rift: Pliocene (Miocene) - Quaternary episode or product of extended development since the Late Cretaceous under various tectonic factors. A review. Geodynamics \& Tectonophysics 6 (4), 467-489. doi:10.5800/GT-2015-6-4-0190.

Для цитирования: Мац В.Д. Байкальский рифт: плиоцен (миоцен) - четвертичный эпизод или продукт длительного развития с позднего мела под воздействием различных тектонических факторов. Обзор представлений // Геодинамика и тектонофизика. 2015. Т. 6. № 4. С. 467-489. doi:10.5800/GT-2015-6-4-0190.

\title{
БАЙКАЛЬСКИЙ РИФТ: ПЛИОЦЕН (МИОЦЕН) - ЧЕТВЕРТИЧНЫЙ ЭПИЗОД ИЛИ ПРОДУКТ ДЛИТЕЛЬНОГО РАЗВИТИЯ С ПОЗДНЕГО МЕЛА ПОД ВОЗДЕЙСТВИЕМ РАЗЛИЧНЫХ ТЕКТОНИЧЕСКИХ ФАКТОРОВ. ОБЗОР ПРЕДСТАВЛЕНИЙ
}

\author{
В. Д. Мац \\ 20101, Кармиель, ул. Шаар Хагай, 13/10, Израиль
}

Аннотация: Рассмотрены представления о возрасте Байкальского рифта (БР) и модели его развития. В литературе обсуждаются три варианта возраста БР - он формируется с позднего плиоцена (5 млн лет), с миоцена или олигоцена (30 млн лет), с позднего мела (60-70 млн лет). Его развитие продолжается в современную эпоху.

Утверждения о молодом - плиоцен-четвертичном - возрасте БР изложены в работах [Artyushkov, 1993; Nikolaev et al., 1985; Buslov, 2012; и дp.]. Е.В. Артюшков считал, что в доплиоценовой Байкальской структуре отсутствуют элементы, свидетельствующие о напряжениях растяжения, и она не рифт, а грабен. Однако 
структуры растяжения (наклонные блоки, листрические разломы) широко распространены в Байкальской впадине (БВ) по всему ее разрезу [Lamakin, 1968; Ufimtsev, 1993; Zonenshain et al., 1995; Mats, 1993, 2012; Mats et al., 2001], и, таким образом, аргументация Е.В. Артюшкова оказалась несостоятельной.

Оживил взгляды о молодом БР М.М. Буслов [Buslov, 2012], который, ссылаясь на исследования в Центральной Азии, считает рифтовой только плиоцен-четвертичную структуру БВ. Древнейшие кайнозойские структуры (верхний мел - миоцен) являются, по М.М. Буслову, фрагментами крупного кайнозойского Предбайкальского предгорного прогиба (ППП) и не имеют отношения к рифту. Однако литолого-формационный состав, мощность отложений и характер тектонических структур одновозрастных кайнозойских образований Предбайкальского прогиба и Байкальской впадины не имеют ничего общего. На разделяющих их пространствах отсутствуют какие-либо отложения и структуры, которые позволили бы соединять в одну структурно-формационную область БР и ППП. Все попытки соединить их в единое образование ничем не обоснованы, и утверждения о плиоценчетвертичном возрасте БР должны быть отвергнуты как противоречащие новейшим геолого-геофизическим данным и не учитывающие то, что сейсмическим профилированием в БВ установлена синрифтовая осадочная толща мощностью более 7.5 км. Этому также противоречит установленный бурением возраст в 8.4 млн лет 600метровой части разреза осадочной толщи Байкала [Horiuchi et al., 2004], тогда как по построениям М.М. Буслова на формирование всей синрифтовой толщи Байкала требуется всего лишь около 5 млн лет.

Наиболее распространено мнение о миоценовом (олигоцен-миоценовом) возрасте БР [Bazarov, 1986; Rasskazov et al., 2014; Mashchuk, Akulov, 2012; Hutchinson et al., 1993; Zonenshain et al., 1995; Kaz'min et al., 1995; и мн. $\partial p$.$] . Оно основано на признании танхойской свиты (миоцен или олигоцен-миоцен) в качестве начинающей$ байкальский синрифтовый разрез, так как она залегает непосредственно на кристаллическом фундаменте рифта, а также на корреляции нижнего сейсмостратиграфического комплекса (ССК-1) с танхойской свитой [Hutchinson et al., 1993; Zonenshain et al., 1995]. Но эти утверждения не учитывают основную закономерность строения разреза развивающегося рифта. Она заключается в том, что наиболее древние элементы синрифтового разреза скрыты в глубинной части рифта, а на дневной поверхности фундамент перекрывают более молодые элементы разреза (эффект несогласия растяжения [Khain, Mikhailov, 1985]). Корреляция ССК-1 с танхойской свитой ошибочна - на представительном сейсмическом профиле видно (рис. 5), как ССК-1, не доходя до дневной поверхности, выпадает из разреза, прислоняясь к подымающемуся склону фундамента, и с танхойской свитой коррелирует ССК-2. Корреляции ССК-1 с танхойской свитой противоречат также данные структурных исследований [San'kov et al., 1997; Delvaux et al., 1997]. ССК-1 формировался до проникновения в Байкальский регион влияния Индо-Евроазиатского столкновения, под воздействием чистого раздвига при ориентировке растягивающих напряжений с С3 на ЮВ вкрест простирания рифта по азимуту ЮВ $145-150^{\circ}$ [Zonenshain et al., 1995]. Ко времени формирования ССК-2 вектор напряжений развернулся против часовой стрелки в направлении СВ-ЮЗ под острым углом субпараллельно к простиранию рифта. Изменилась структура Байкальского рифта - одностороннюю впадину сменил двухсторонний грабен, простирающийся к Ю3СВ, выполненный ССК-2 и ограниченный листрическими сбросами [Zonenshain et al., 1995].

Структурными исследованиями на суше, окружающей Байкал, установлено, что в танхойское время рифт развивался в обстановке транспрессии и транстензии, под воздействием напряжений, ориентированных субпараллельно простиранию рифта и связанных с Индо-Евроазиатской коллизией [San'kov et al., 1997; Delvaux et al., 1997; Parfeevets, San'kov, 2006]. Таким образом, с танхойской свитой, по данным структурных исследований, коррелируется не ССК-1, а ССК-2, возраст танхойской свиты не является показателем возраста БР, и представление о его миоценовом (олигоцен-миоценовом) возрасте должно быть отвергнуто.

Наиболее полно имеющимся геолого-геофизическим данным соответствует вывод о позднемеловомпалеогеновом возрасте БР [Logachev, 1974, 2003; Mats, 1987, 1993, 2012; Mats et al., 2001; Mats, Perepelova, 2011]. Это утверждение базируется на обнаружении в керне глубоких скважин, пробуренных в дельте р. Селенги (Южнобайкальская впадина), палеогеновых (эоцен) палиноспектров [Faizulina, Kozlova, 1966]. Кроме того, на хамар-дабанском побережье Южного Байкала (р. Половинка) обнаружены палеоцен-эоценовые дотанхойские отложения [Mats, 2013]. Отложения формации коры выветривания БВ коррелируются [Mats, 2013] с палеонтологически датированными палеогеновыми отложениями Предбайкальского прогиба [Pavlov et al., 1976; Popova, 1981]. Древний возраст БВ подтвержден также в работах [Nikolaev, 1998; Galazii et al., 1999; Kontorovich et al., 2007; Jolivet et al., 2009].

Обзор обсуждаемых представлений о возрасте БР приводит к заключению о необходимости исключить из рассмотрения заявления о его плиоцен-четвертичном и олигоцен-миоценовом («танхойском») возрасте как не отвечающие современным геолого-геофизическим данным.

Удлинение возраста БР до 60-70 млн лет и его комплексное изучение позволили сформулировать новый взгляд на Байкальский рифтогенез и предложить вместо известной двухэтапной модели его формирования [Logachev, 2003] трехэтапную (рис. 6), а также дополнить пассивную и активную модели рифтогенеза третьей - импактогенной [Mats, 2012; Mats, Perepelova, 2011].

На первом этапе - поздний мел - ранний олигоцен (70-30 млн лет) - БР формировался в условиях общего рассеянного растяжения литосферы в виде щелевого (по Е.Е. Милановскому) рифта, по пассивной модели, на фоне исходного пенеплена и до проникновения в Байкальский регион напряжений, продуцируемых ИндоЕвроазиатским столкновением. Структура рифта была образована в виде односторонней впадины, ограниченной с северо-запада зоной листрических сбросов и выполненной сейсмически прозрачным сейсмостратиграфическим комплексом - ССК-1.

На втором этапе - поздний олигоцен - ранний плиоцен (30-5 млн лет) - БР развивался под воздействием напряжений, продуцируемых Индо-Евроазиатским столкновением. Был образован двухсторонний грабен, выполненный слоистым деформированным ССК-2.

На третьем этапе - поздний плиоцен - квартер (5 млн лет тому назад - современность) - рифт развивался под воздействием местных глубинных источников напряжений, по активной модели [Logachev, Zorin, 1987; 
V.D. Mats: The Baikal rift: Pliocene (Miocene) - Quaternary episode or product of extended development...

Zorin et al., 2003]. Вновь сформировался односторонний грабен, ограниченный с северо-запада листрическими разломами, выполненный слоистым недеформированным комплексом (ССК-3).

Ключевые слова: Байкальский рифт; возраст; поздний мел - современность; трехэтапная модель формирования; активная, пассивная и импактогенная модели рифтогенеза

\section{1. ВВЕДЕНИЕ}

Байкальский рифт - признанный тектонотип структур континентального рифта. Выяснение особенностей процессов его формирования, его строения и развития имеет общее значение и может быть положено в основу модели континентального рифтогенеза. Одной из важных его характеристик служит определение длительности развития.

В литературе обсуждается три варианта возраста Байкальского рифта. Наиболее распространено (общепринято) представление о начале байкальского рифтогенеза с миоцена, олигоцена [Bazarov, 1986; Zonenshain et al., 1995; Kaz'min et al., 1995; Rasskazov et al., 2014; Mashchuk, Akulov, 2012; и мн. дp.]. Это мнение опирается на «танхойский феномен»залегание танхойской свиты непосредственно на кристаллическом фундаменте. Таким образом, начало рифтогенеза определяется возрастом танхойской свиты, а длительность развития составляет порядка 30 млн лет. Согласно иной точке зрения, Байкальский рифт образовался лишь на плиоценчетвертичном этапе - 5 млн лет назад [Artyushkov, 1993; Nikolaev et al., 1985; Buslov, 2012; и дp.]. Однако в других исследованиях начало байкальского рифтогенеза отодвинуто в поздний мел, а его длительность составляет порядка 60-70 млн лет [Logachev, 1974, 2003; Mats, 1987, 1993, 2012, 2013; Mats et al., 2001; Jolivet et al., 2009; Mats, Perepelova, 2011].

На современной стадии исследований всякое рассмотрение вопроса о возрасте и развитии Байкальского рифта не релевантно без учета сейсмостратиграфического изучения осадочной толщи, выполняющей структуру, результатов комплексных геологических исследований, с учетом материалов глубоководного бурения донной толщи и геофизического изучения региона. При этом следует исходить из достоверно установленного факта заполнения Байкальской впадины тремя синрифтовыми сейсмостратиграфическими комплексами (ССК): ССК-1, ССК-2 и ССК-3 [Zonenshain et al., 1995]. Таким образом, время начала Байкальского рифтогенеза определяется возрастом ССК-1, и решение проблемы зависит от корреляции ССК-1 с теми или иными датированными элементами разреза третичных отложений Прибайкалья - тектонолитостратиграфическими комплексами (ТЛСК).

Проведенные исследования показали, что попытка свести формирование Байкальского рифта к плиоцен-четвертичному эпизоду не соответствует сумме знаний о его геологии и геофизике. Даже сама огромная мощность синрифтового осадочного тела - более 7 км - отвергает такую возможность. Представление о миоцен (олигоцен) - четвертичном возрасте байкальского рифтогенеза входит в противоречие с известными закономерностями формирования синрифтового осадочного клина, результатами структурных исследований, а также с прямыми данными о наличии палеогеновых (эоценовых) отложений в разрезе рифта. Таким образом, утверждение о том, что возраст Байкальского рифта определяется возрастом танхойской свиты, с нашей точки зрения, также не соответствует известным фактам.

Только признание позднего мела (палеогена?) временем начала байкальского рифтогенеза отвечает всей сумме современных геологических и геофизических данных.

Рассмотрим различные точки зрения о возрасте Байкальского рифта.

\section{2. БАЙКАЛЬСКИЙ РИФТ - МОЛОДОЕ ПЛИОЦЕН- ЧЕТВЕРТИЧНОЕ ОБРАЗОВАНИЕ?}

Ряд исследователей [Artyushkov, 1993; Nikolaev et al., 1985; Buslov, 2012; и др.] полагают, что Байкальский рифт образовался лишь на плиоцен-четвертичном этапе. Этот взгляд восходит к палеогеографическим и палеотектоническим представлениям H.A. Флоренсова [Florensov, 1960] и Н.А. Логачева [Logachev, 1958, 1968], которые тогда считали, что в миоцене (танхойский этап) в Байкальском рифте были мелководные озера, болота, границы бассейна седиментации не определялись разломными структурами и не совпадали с современными границами распространения миоценовых отложений. Соответственно тектонический режим был вялым, не рифтовым. Позднее Н.А. Логачев писал о «...превращении палеоген-неогеновых котловин в 
рифтовые впадины» [Logachev, 1974, c. 113] в середине плиоцена. Из этого противопоставления можно, казалось бы, понять, что палеоген-неогеновые структуры (котловины) не являются рифтовыми. Но и тогда, и в своей последней публикации Николай Алексеевич, сохраняя понятие «котловины» за ранними байкальскими структурами, однозначно определяет их как структуры рифта [Logachev, 2003].

Биологи, изучавшие малакофауну Танхойского местонахождения, всегда утверждали, что Танхойский бассейн был глубоководным [Martinson, 1951; Kozhov, 1972; Popova, 1981]. Позднее были найдены геологические аргументы глубоководного рифтового бассейна танхойского времени, границы которого определялись разломами, практически совпадали с современными и однозначно определялись как структуры рифта [Mats, 1985]. Бурение донных отложений подтвердило глубоководность миоценового бассейна [Kuz'min et al., 2001].

E.В. Артюшков аргументировал свое мнение якобы отсутствием признаков растягивающих напряжений в доплиоценовой байкальской морфоструктуре, в которой отсутствуют наклонные блоки, ограниченные листрическими сбросами, - доказательство растягивающих напряжений. Таким образом, доплиоценовая байкальская структура не рифт, а грабен.

Но исследования в области сухопутного окружения Байкала [Lamakin, 1968; Pleshanov, Romazina, 1981; Ufimtsev, 1993; Mats, 1987, 1993, 2012; Mats et al., 2001; Mats, Perepelova, 2011; и дp.] и в структуре донной толщи [Hutchinson et al., 1993; Zonenshain et al., 1995; Kaz'min et al., 1995] показали повсеместное распространение наклонных блоков и оконтуривающих их листрических сбросов и в доплиоценовых структурах. Таким образом, аргументация Е.В. Артюшкова оказалась несостоятельной.

Однако признание за Байкальской впадиной рифтовой природы лишь на плиоцен-четвертичном этапе ряд исследователей разделяет и сейчас. В одной из недавних публикаций [Buslov, 2012] утверждается, что «байкальская система сдвигов и сопряженных рифтов образована в плиоцен-четвертичное время как результат дальнего воздействия Индо-Евразийской коллизии» [Buslov, 2012, c. 1245] ${ }^{1}$. Мел-палеогеновые и миоцен-раннеплиоценовые комплексы Байкальской впадины есть не что иное, как «уцелевшие фрагменты» некогда единого обширного Предбайкальского прогиба, и,

\footnotetext{
1 Здесь и далее указания на страницы в работе [Buslov, 2012] даны для русскоязычной версии статьи: Буслов М.М. Геодинамическая природа Байкальской рифтовой зоны и ее осадочного выполнения в мел-кайнозойское время: эффект дальнего воздействия Монголо-Охотской и Индо-Евроазиатской коллизий // Геология и геофизика. 2012. Т. 53. № 9. С. 1245-1255.
}

соответственно, они не имеют отношения к рифтовым структурам [Buslov, 2012, c. 1251 и 1252]. Лишь плиоцен-четвертичный комплекс, который в наиболее полном виде представлен в Усть-Селенгинской впадине, формировался в «обстановке активной рифтовой структуры»[Buslov, 2012, с. 1251]. Уточняя сказанное, автор пишет:

a) нижний - мел-палеогеновый - комплекс Байкальской впадины - сейсмостратиграфический комплекс-1 (ССК-1) «...является фрагментом позднемеловых-палеогеновых образований крупного Предбайкальского предгорного прогиба» [Buslov, 2012, с. 1252];

б) средний сейсмостратиграфический комплекс Байкальской впадины «...является фрагментом верхнеолигоценового-нижнеплиоценового крупного Предбайкальского прогиба» [Там же, с. 12511252];

в) верхний комплекс Байкальской впадины «...формировался... в обстановке активной рифтовой структуры» [Там же, с. 1251].

Поскольку автор в обоснование своей точки зрения привлекает ранее не использовавшиеся аргументы и построения и так как его статья обозначена в качестве дискуссионной, а в «...основу дискуссии положены материалы и выводы работ, обобщенных в статье В.Д. Маца (2012)» [Buslov, 2012 , c. 1246], рассмотрим его взгляды более подробно и проверим высказанные положения с точки зрения их соответствия региональным геологическим данным, не оставляя в стороне и иные существующие представления.

Как установлено сейсмостратиграфическими исследованиями, донная толща Байкальской впадины включает три (рис. 1) синрифтовых сейсмостратиграфических комплекса (ССК): нижний - ССК-1 прозрачный, средний - ССК-2 - слоистый деформированный и верхний - ССК-3 - слоистый недеформированный [Hutchinson et al., 1993; Zonenshain et al., 1995; Moore et al., 1997]. В работе [Kaz'min et al., 1995] ССК-2 подразделен на ССК-2-1 и ССК-2-2 с границей в середине миоцена - северобайкальская тектоническая фаза [Mats, 2012] около 10 млн лет (табл. 1).

На суше, окружающей Байкал, кайнозойские отложения Байкальской впадины расчленяются на три ТЛСК, разделенных несогласиями - ТЛСК-1 позднемеловой-раннеолигоценовый, ТЛСК-2 - позднеолигоценовый-раннеплиоценовый, подразделенный на ТЛСК-2-1 и ТЛСК-2-2 с границей между ними в середине миоцена, и ТЛСК-3 - позднеплиоценчетвертичный [Mats, 2012; Mats, Perepelova, 2011]. В этих работах предложена также корреляция ССК-1 с ТЛСК-1; ССК-2 с ТЛСК-2 и ССК-3 с ТЛСК-3. Тем самым, соответственно, определен возраст ССК и синрифтовый характер ТЛСК (табл. 1). М.М. Буслов 
V.D. Mats: The Baikal rift: Pliocene (Miocene) - Quaternary episode or product of extended development...

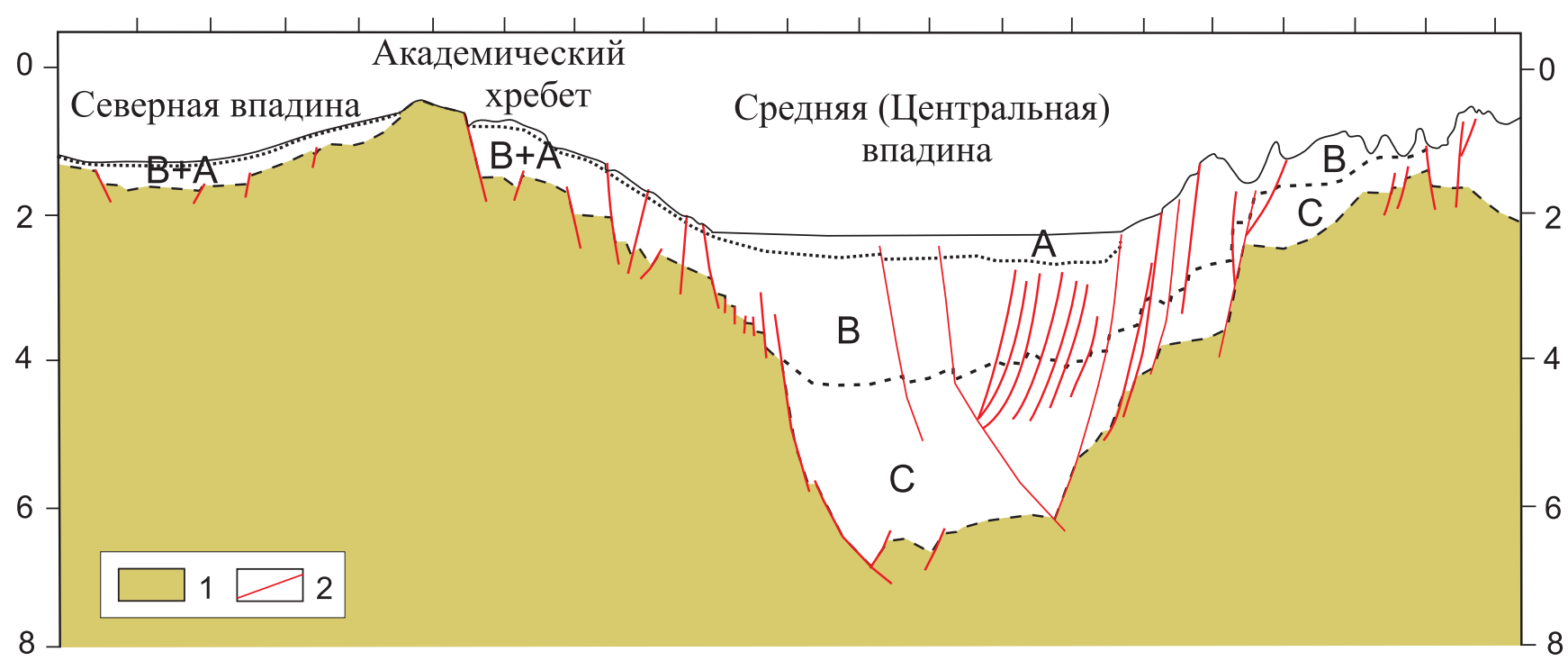

Рис. 1. Строение осадочной толщи Байкальской впадины по данным многоканального сейсмического профилирования.

Интерпретация сейсмического профиля через Академический хребет и примыкающие к нему Северобайкальскую и Среднебайкальскую впадины [Hutchinson et al., 1993], с изменениями и дополнениями. А - слоистый недеформированный комплекс - ССК-3 (верхний плиоцен - квартер); В - слоистый деформированный комплекс - ССК-2 (верхний олигоцен - нижний плиоцен); С прозрачный сейсмический комплекс - ССК-1 (верхний мел - нижний олигоцен). 1 - дорифтовый фундамент; 2 - разлом.

Fig. 1. Sediments of the Baikal basin from multichannel seismic profiling data.

Interpretation of the seismic profile across the Academician ridge and neighbouring North Baikal and Middle Baikal basins (modified after [Hutchinson et al., 1993]). Seismostratigraphic complexes (SSC): A - SSC-3, stratified non-deformed complex (Upper Pliocene - Quarter); B - SSC-2, stratified deformed complex (Upper Oligocene - Lower Pliocene); C - SSC-1, transparent seismic complex (Upper Cretaceous Lower Oligocene). 1 - pre-rift basement, 2 - fault.

принимает предложенную нами корреляцию, что позволяет в рамках данного исследования исходить из этого как из установленного факта.

Для оценки построений в работе [Buslov, 2012] необходимо рассмотреть взаимоотношения отложений Байкальской впадины (БВ) и Предбайкальского предгорного прогиба (ППП): являются ли ТЛСК-1 и ТЛСК- 2, а также ССК-1 и ССК-2 фрагментами одновозрастных нерифтовых комплексов ППП - ТЛСКПр. Или доплиоценовые образования БВ - это рифтовые комплексы? И может ли УстьСеленгинский разрез рассматриваться как представитель ССК-3, «единственный, формировавшийся в обстановке активной рифтовой структуры»?

\section{1. МЕЛ-ПАЛЕОГЕНОВЫЙ И МИОЦЕН (ОЛИГОЦЕН?) - РАННЕПЛИОЦЕНОВЫЙ КОМПЛЕКСЫ БАЙКАЛЬСКОЙ ВПАДИНЫ - ФРАГМЕНТЫ ПРЕДБАЙКАЛЬСКОГО ПРЕДГОРНОГО ПРОГИБА?}

Н.А. Логачев много лет назад сформулировал представление о синхронности и некоей общей связи развития Предбайкальского предгорного прогиба и Байкальской впадины [Logachev, 1974; u $\partial p$.]. Но при этом он и другие исследователи уста- новили принципиальные формационные различия толщ, выполняющих эти структуры, и самих структур [Logachev, 1974; Pavlov et al., 1976; Zamaraev et al., 1976; Mats et al., 2004; u dp.].

Это особенно наглядно установлено сейсмостратиграфическими исследованиями Байкальской впадины [Zonenshain et al., 1995; Kaz'min et al., 1995]. ССК-1 коррелятен ТЛСК-1 и представляет позднемеловой-палеогеновый рифтовый комплекс (табл. 1). Он выполняет односторонний грабен, сформировавшийся в зоне разломов краевого шва Сибирской платформы на фоне мел-палеогенового пенеплена - щелевой рифт по Е.Е. Милановскому. Прогиб образовался по схеме чистого раздвига, в условиях общего рассеянного растяжения, трансформировавшегося в древней «зоне слабости» древнем разломе - в напряжения растяжения, ориентированные вкрест простирания рифта по азимуту ЮВ 145-150 [Zonenshain et al., 1995]. Он слагает типичное для синрифтовых образований тело клиновидной формы (рис. 1). С запада, т.е. со стороны, обращенной к Предбайкальскому прогибу, ССК-1 ограничен краевыми листрическими разломами. Их листрический характер обусловливает общий наклон фундамента впадины к западу, в 


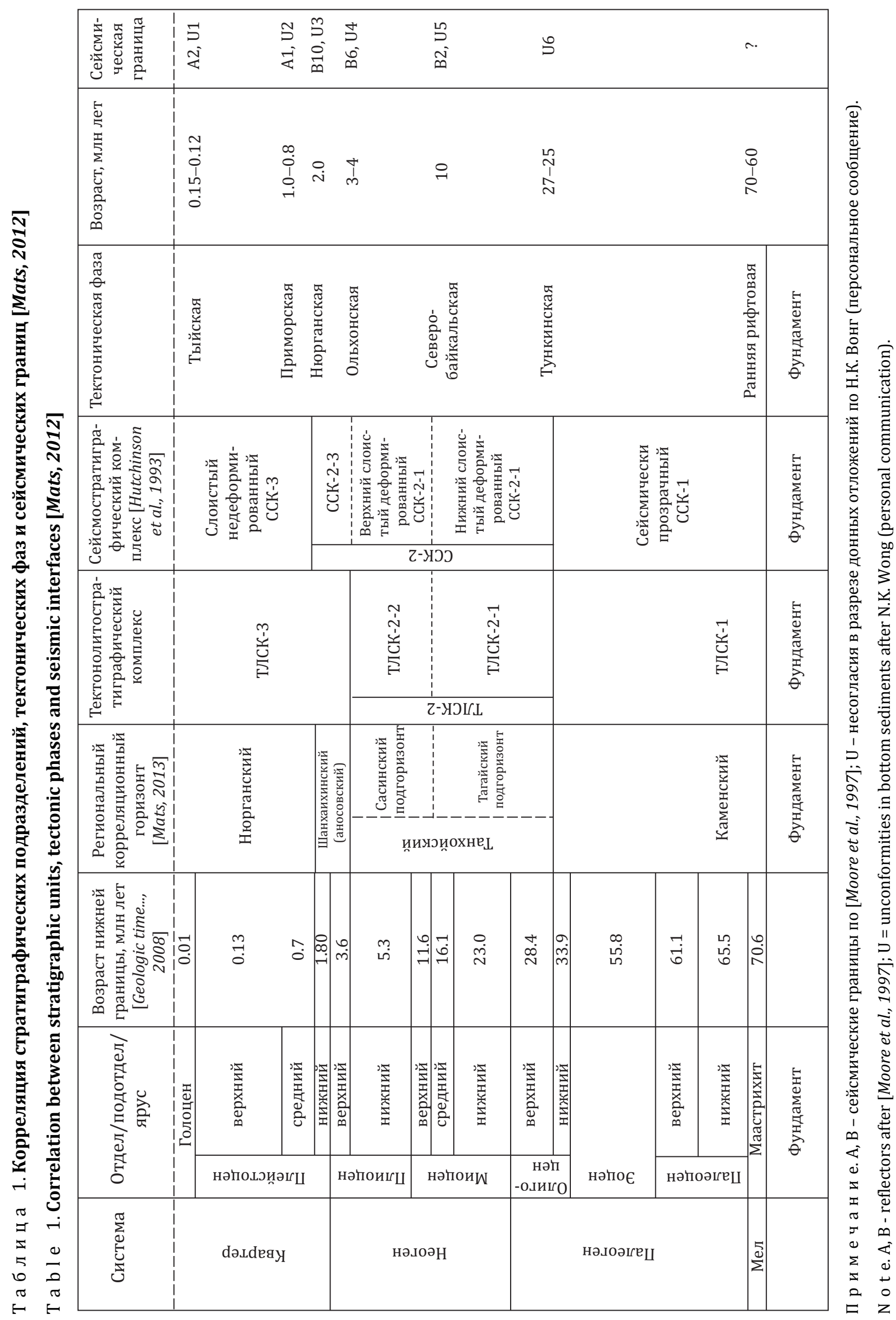




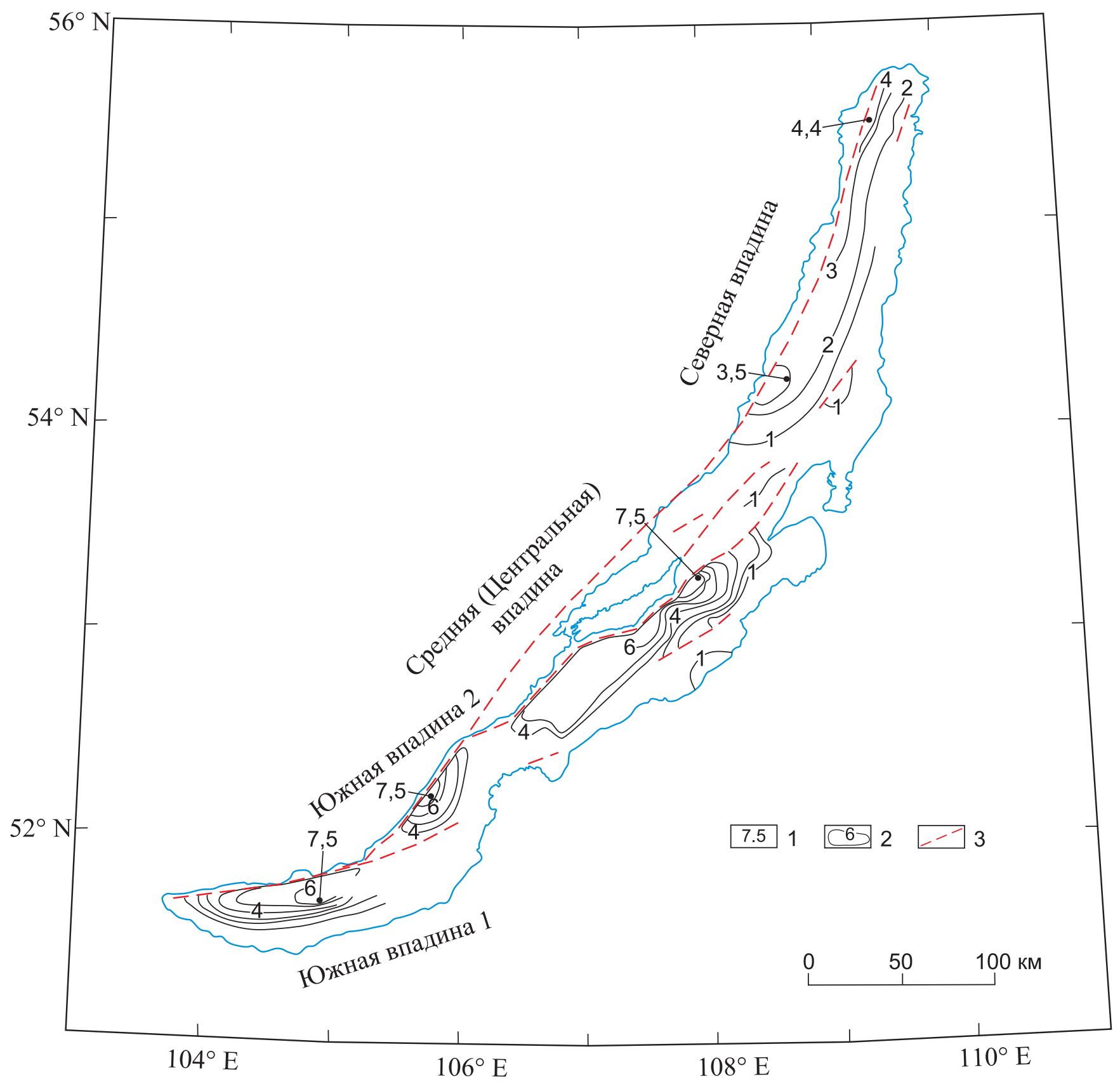

Рис. 2. Карта мощности осадочной толщи Байкальской впадины по данным непрерывного сейсмического профилирования (по [Hutchinson et al., 1993], с изменениями). 1 - мощность в депоцентре, км; 2 - изопахиты; 3 - основные разломы.

Fig. 2. The Baikal basin sediments thickness map based on continuous seismic profiling data (modified after [Hutchinson et al., 1993]). 1 - thickness in the depocentre, km; 2 - isopachites; 3 - main faults.

связи с чем к западному ограничению впадины прижаты депоцентры осадочной толщи БВ, где она достигает 7500 м (рис. 2). Мощность ССК-1 меняется от 4000 м в депоцентрах до 1000 м у противоположного борта [Hutchinson et al., 1993; Zonenshain et al., 1995]. Литологический состав ССК-1 малоизвестен, так как древнейшие элементы синрифтового разреза остаются в глубине рифта [Khain, Mikhailov, 1985; Mats et al., 2001], и о них можно судить лишь по обрывочным данным о бассейновых отложениях и многочисленным сведениям о их субаэральных аналогах - ТЛСК-1 [Pavlov et al., 1976; Dombrovskaya, 1973; Granina et al., 2010; Mats, Yefimova, 2010, 2011; Mats, 2013; Mats et al., 2001].

Отложения, слагающие ТЛСК-1, их субаэральная часть, так же как и нижний (позднемеловой - раннеолигоценовый) тектонолитостратиграфический комплекс - ТЛСКПр-1, принадлежат формации ко- 
ры выветривания - в широком смысле и образованы мономиктовыми продуктами плоскостного смыва с мел-палеогенового пенеплена, покрытого каолинит-латеритной корой выветривания [Zanin, 1975; Pavlov et al., 1976]. Они формировались в климатических условиях влажных субтропиков (квазитропиков по В.M. Синицыну [Sinitsyn, 1967]), в обстановке, которая позднее не повторялась, что определяет надежность литолого-формационных корреляций [Mats, 2013; Mats et al., 2001]. Но литологические особенности ТЛСК-1 наглядно проявляются главным образом в субаэральных фациях. В их составе распространены бокситы, континентальные фосфориты как продукт латеритного выветривания древних морских фосфоритов, многочисленные разнообразные формы Fe/Mn выделений - натеки, метасоматические образования, озерно-болотные руды и т.п., каолинитовые глинистые отложения, кварц-кварцитовые пески, галечники [Zanin, 1975; Pavlov et al., 1976; Mats, Yefimova, 2010, 2011; Granina et al., 2010]. Но очевидно, что огромная толща осадков, достигающая 4000 м, не могла быть образована только продуктами плоскостного смыва с поверхности пенеплена. В ее составе также присутствуют продукты эрозионного размыва, включающие и полимиктовуюолигомиктовую составляющую. Так, отложения ТЛСК-1, залегающие под танхойской свитой на p. Половинке (Хамар-Дабанское побережье), характеризуются олигомиктовым составом (табл. 2). Это согласуется с тем, что пенепленизация временами прерывалась оживлением вертикальных тектонических движений, зафиксированным формированием крутых склонов высотой до 50 м, что сопровождалось прорезанием водотоками плаща коры выветривания, поступлением в бассейны седиментации не измененного выветриванием минерального вещества и смещением пенепленизации на более низкий гипсометрический уровень. В Предбайкальском прогибе установлено два эпизода расчленения пенеплена [Zamaraev et al., 1976], в Западном Прибайкалье - один. Верхний уровень здесь покрыт красными каолинитовыми глинами, нижний - желтыми, что можно рассматривать как свидетельство климатических изменений. Ступени пенеплена разделены крутым склоном высотой порядка 30 м [Mats, Yefimova, 2010]. Вполне очевидно, что эти свидетельства оживления тектонической активности сопровождались поступлением в зону седиментации продуктов размыва первичных пород фундамента.

Пространственное ограничение Байкальской впадины с запада соответствует первичной границе рифтовой структуры и бассейна седиментации. На всем пространстве между Байкальской впадиной и Предбайкальским прогибом отсутству- ют какие-либо следы - признаки былого существования здесь структур и отложений, хоть в чем-либо сходных с сейсмостратиграфическими комплексами Байкальской впадины. Развитые там отложения и структуры не имеют ничего общего с характерными для Байкальской рифтовой впадины [Mats, Yefimova, 2010, 2011; Granina et al., 2010]. Более того, распространение здесь различных генетических типов отложений показывает, что основа современных морфоструктур Западного Прибайкалья была заложена еще в позднем мелу - палеогене [Mats et al., 2001; Mats, Yefimova, 2010, 2011]. Таким образом, западная граница Байкальской впадины соответствует первичному ограничению байкальского рифтового бассейна седиментации, который не распространялся в сторону Предбайкальского прогиба.

Стратиграфические (и только стратиграфические) аналоги ССК-1 в Предбайкальском прогибе едва достигают мощности в первые сотни метров [Zamaraev et al., 1976; Pavlov et al., 1976; Mats et al., 2004], выполняя небольшие частные прогибы, т.е. структуры совершенно иного типа, чем структура Байкальского рифта, в которой отложения ССК-1 достигают мощности до 4000 м и которую специалисты, проводившие сейсмостратиграфические исследования, доказательно и вполне однозначно определили как рифтовую [Zonenshain et al., 1995; u dp.]. Ничего подобного многокилометровым асимметричным телам Байкальского рифта в Предбайкальском прогибе нет [Zamaraev et al., 1976; Pavlov et al., 1976]. Никакой связи с листрическими сбросами структуры Предбайкальского прогиба не обнаруживают (рис. 3).

Пространственно Предбайкальский прогиб и Байкальская впадина разобщены серией разнотипных морфоструктур, не имеющих ничего общего со структурно-вещественными комплексами БВ. Это принципиально различные структуры! Нет никаких оснований рассматривать ССК-1 как «фрагмент Предбайкальского прогиба». Это голословное утверждение, не обоснованное никакими фактами и аргументами [Buslov, 2012].

Средний сейсмостратиграфический комплекс ССК-2 - аналог распространенных на окружающей Байкал суше верхнеолигоценовых-нижнеплиоценовых отложений (танхойская и осиновская свиты - ТЛСК-2) и стратиграфический (и только стратиграфический) аналог миоценовых толщ Предбайкальского прогиба (баяндайская и байшинская свиты - ТЛСКПр-2).

Но средние комплексы Байкальской впадины (ТЛСК-2 и ССК-2) и Предбайкальского прогиба (ТЛСКПр-2) принципиально различны в структурном, литолого-формационном отношении и по мощности отложений. 

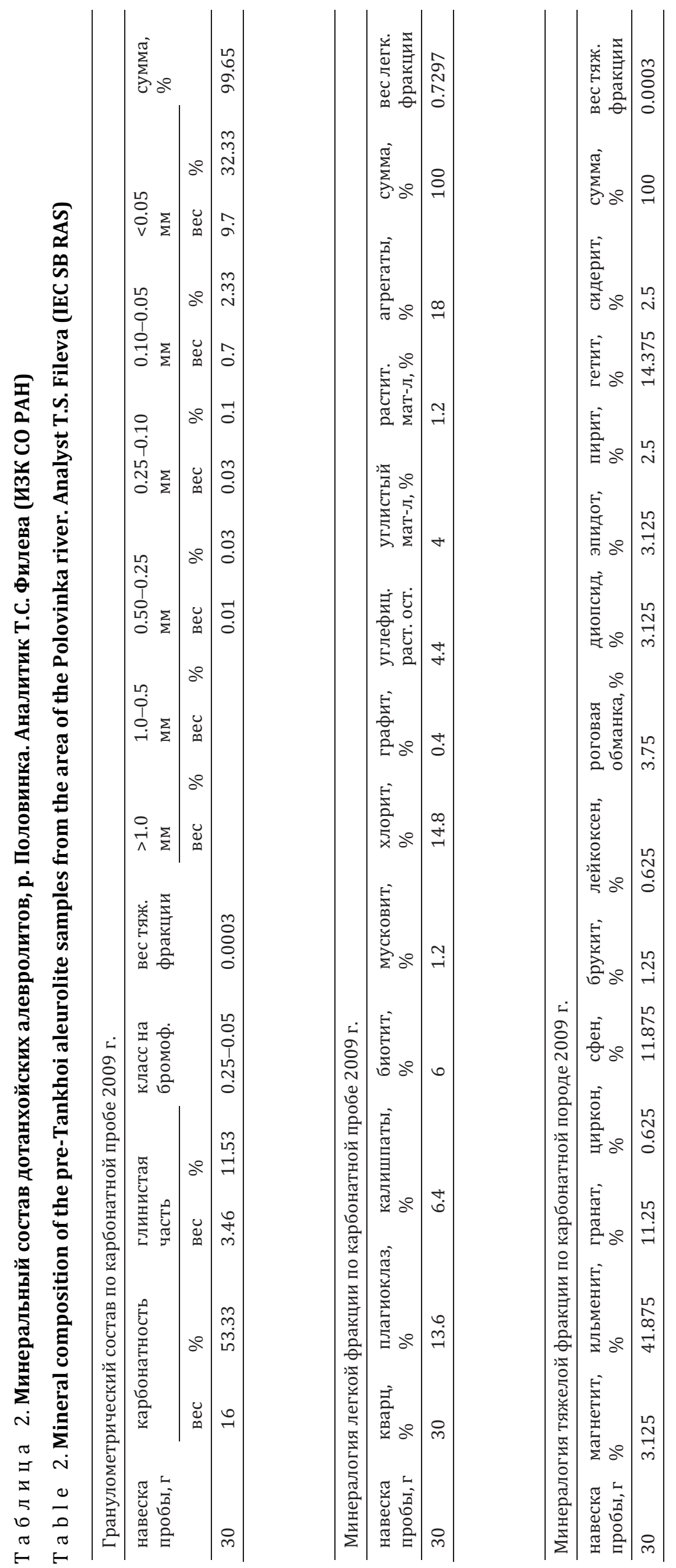

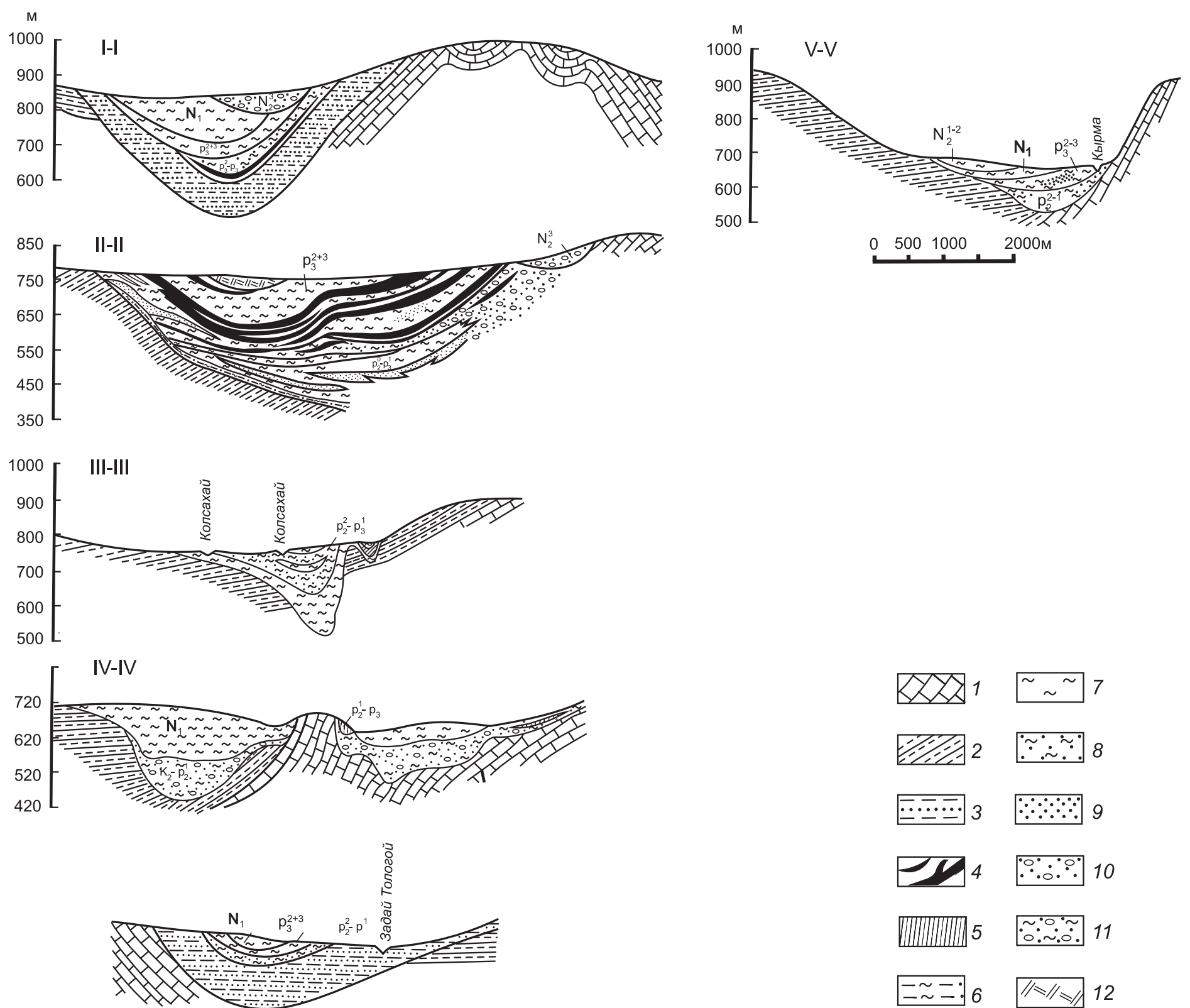

Рис. 3. Геологические разрезы впадин Предбайкальского предгорного прогиба [Zamaraev et al., 1976, c. 100-101, рис. 22].

1-3 - породы фундамента: 1 - нижний-средний кембрий, 2 - средний верхний кембрий, 3 - нижняя юра; 4-12 - отложения Предбайкальского прогиба: 4 - угли, 5 - бокситы и бокситоподобные породы, 6 - структурный элювий, 7 - глины, 8 - суглинки, супеси, 9 - пески, 10 - валунно-галечно-песчаные отложения, 11 - глинисто-песчаные отложения, 12 - четвертичные озерноболотные отложения.

Fig. 3. Geological cross-sections of basins in the Predbaikalsky submontane trought (Fig. 22, p. 100-101 in [Zamaraev et al., 1976]).

1-3 - basement rocks: 1 - Lower-Middle Cambrian, 2 - Middle Upper Cambrian, 3 - Lower Jurassic; 4-12 - sediments of the Predbaikalsky trough: 4 - coal, 5 - boxite and boxite-like rocks, 6 - structural eluvium, 7 - clay, 8 - loamy clay, sandy loam, 9 - sand, 10 - cobble-pebblesandy deposits, 11 - clayey-sandy deposits, 12 - Quaternary lacustrine-boggy deposits.

ТЛСКПр-2 сложен мелководными глинисто-карбонатными угленосными отложениями небольших засолоненных озер с пластами пресноводных известняков, торфяных болот (промышленные угольные месторождения) общей мощностью 170-340 м, выполняющих неглубокие плоские понижения, разделенные невысокими возвышенностями. Границы поднятий с прогибами (рис. 3) имеют характер полого воздымающихся склонов [Pavlov et al., 1976; Zamaraev et al., 1976] и никак не напоминают 
V.D. Mats: The Baikal rift: Pliocene (Miocene) - Quaternary episode or product of extended development...

разломные ограничения байкальских морфоструктур. Вся эта система, в противоположность Байкальской, характеризовалась низким уровнем тектонической активности.

В БВ был развит совершенно иной тип седиментационных бассейнов и примыкающих к ним водоразделов. На Южном и Среднем Байкале существовали крупные рифтовые [Zonenshain et al., 1995] впадины, занятые глубоководными озерами. Краевые фации Южнобайкальского бассейна ТЛСК-2 - сложены миоценовыми танхойской и осиновской свитами. Они представлены мощными, до 1000 м, полимиктовыми, частично граувакковыми, бескарбонатными глинисто-песчано-алевритовыми отложениями крупных глубоководных озер - продукт эрозионного размыва не измененных выветриванием пород кристаллического фундамента. В прибрежной зоне присутствуют маломощные угольные пласты (первые десятки сантиметров, в единичных случаях до 5 м), выклинивающиеся в глубь бассейна (танхойская свита). Мелкоземистые фации местами замещаются грубообломочными отложениями (осиновская свита), в составе которых присутствуют аллювиальные, аллювиально-озерные, прибрежно-озерные образования, местами также содержащие угольные пропластки [Mats, 1985; Rasskazov et al., 2014]. По химическому составу [Mats et al., 2001] отложения танхойской свиты близки к характерным для геосинклиналей, заложенным на континентальной земной коре [Krasnov, 1987].

В танхойской свите изучено крупное местонахождение малакофауны, в составе которой установлены виды, родственные видам из индо-китайской зоогеографической провинции. Эта малакофауна по видовому составу, экологически и по родственным связям резко отлична от малакофауны баяндайской свиты [Popova, 1981]. По своим литолого-формационным особенностям ТЛСК-2 - типичная нижняя моласса.

Геологическая структура ССК-2 представлена двухсторонним грабеном, ограниченным листрическими сбросами. Структура Предбайкальского прогиба не имеет ничего общего с подобными грабенами и представлена, как уже сказано, неглубокими синклиналеподобными опусканиями (рис. 3).

Вектор тектонических напряжений при формировании ССК-2 был повернут по часовой стрелке относительно вектора при формировании ССК-1 и был направлен субпараллельно оси рифта по направлению CВ-Ю3 [Zonenshain et al., 1995]. Такое же направление тектонических напряжений установлено для танхойского времени. Напряжения косого сжатия в первой половине этого периода сменились напряжениями косого растяжения [Delvaux et al., 1997].
Таким образом, все особенности отложений, областей сноса и осадконакопления ТЛСК-2 (ССК-2) и ТЛСКПр-2 однозначно противоречат попытке признать позднеолигоценовые-раннеплиоценовые отложения Байкальской впадины фрагментом образований Предбайкальского прогиба, как это утверждает М.М. Буслов. Противоречат этому и результаты структурных исследований [San'kov et al., 1997; Delvaux et al., 1997].

\section{2. ВЕРХНИЙ КОМПЛЕКС - ССК-3 - ПЛИОЦЕН-ЧЕТВЕРТИЧНОГО ВОЗРАСТА - ЕДИНСТВЕННЫЙ ПРОДУКТ АКТИВНОГО РИФТОГЕНЕЗА?}

Этот тезис частично соответствует истине, но его ложность заключается в противопоставлении его рифтового характера якобы нерифтовому типу структур нижнего и среднего комплексов, а также в попытке выдать в качестве типового рифтового комплекса плиоцен-четвертичного возраста разрез глубоких (до 3100 м) скважин в дельте р. Селенги селенгинская толща. Однако этот разрез (рис. 4) включает, кроме плиоцен-четвертичных, также миоценовые и палеогеновые отложения [Zamaraev, Samsonov, 1959; Faizulina, Kozlova, 1966; Logachev, 1974; Imetkhenov, 1987; Rasskazov et al., 2014], причем фундамент залегает на глубинах до 5-6 км. Таким образом, селенгинская толща никак не может служить типом плиоцен-четвертичного рифтового комплекса.

В подтверждение своих взглядов М.М. Буслов приводит данные по Алтае-Саянской области, где «...осадки этого возраста расположены в рампах и односторонних рампах, сформированных в плиоцене-квартере (последние 5 млн лет), совместно с растущими рядом горными системами. Горные поднятия разделили на серию межгорных впадин ранее единый крупный кайнозойский бассейн осадконакопления» [Buslov, 2012, c. 1251]. В АлтаеСаянской области было так, но означает ли это, что то же происходило и в Байкальском рифте? Усомниться в этом заставляет простое сопоставление ориентировки структур - структуры Алтае-Саянской области ориентированы поперек направления напряжений, обусловленных Индо-Евроазиатской коллизией, и они, естественно, развивались по рамповому типу, тогда как байкальские структуры направлены субпараллельно этим напряжениям. Соответственно, структурная реакция Алтае-Саянской и Байкальской областей была различна - в Алтае-Саянской области формировались рамповые структуры, тогда как в Байкальской области, в условиях косого растяжения [Delvaux et al., 1997], был сформирован комплекс рифтовых структур.

Вполне очевидную роль ориентировки структур наглядно иллюстрирует различная реакция Саян- 


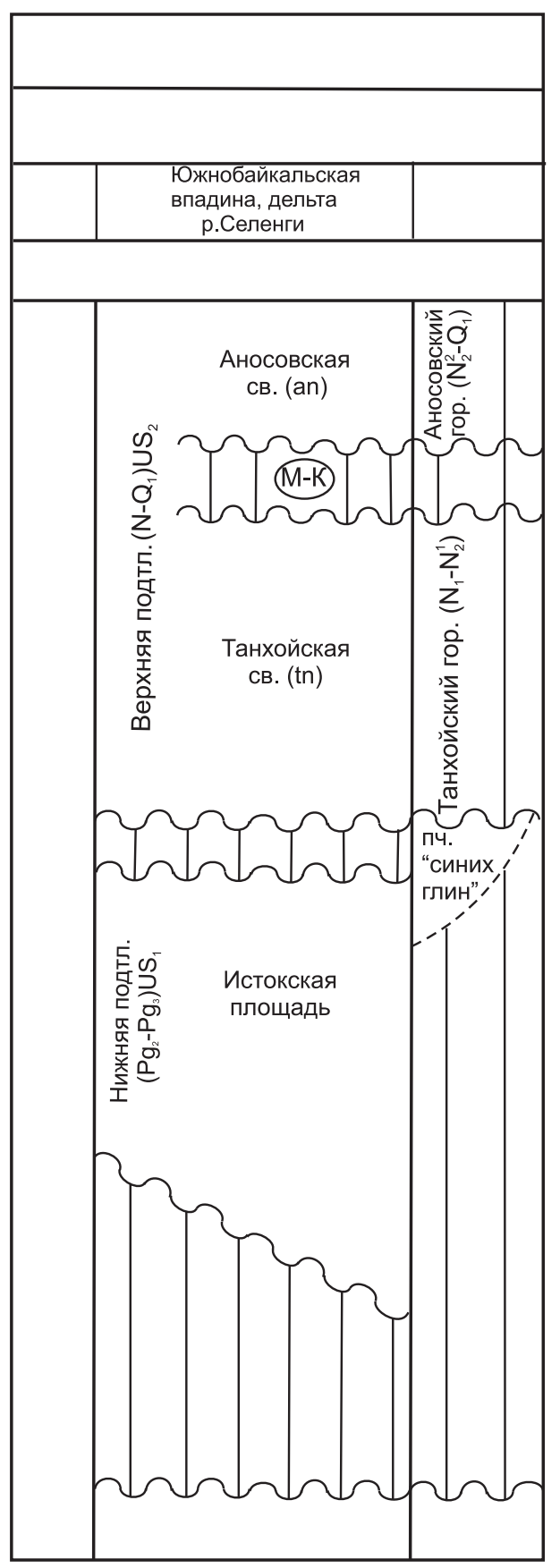

Рис. 4. Селенгинская толща, Южнобайкальская впадина, дельта р. Селенга [Rasskazov et al., 2014].

Fig. 4. The Selenga bed, South Baikal basin, Selenga River delta [Rasskazov et al., 2014].

ской и Байкальской ветвей юга Сибирской платформы на напряжения, продуцируемые Индо-Евроазиатским столкновением, - в субпараллельно ориентированной Байкальской ветви развивался рифт, тогда как в Саянской ветви развилась система структур сжатия в виде надвигов, взбросонадвигов.

Среди различных аргументов, которые М.М. Буслов в подтверждение своей концепции широко использует, данные трекового датирования апатитов, приведенные в [Jolivet et al., 2009]. Даны результаты трекового датирования, полученные, в том числе, по территориям, весьма удаленным от рассматриваемого региона. Единственное, что отсутствует, - это результаты такого датирования, имеющие непосредственное отношение к рассматриваемой проблеме - проблеме возраста Байкальского рифта. Следует напомнить, что авторы работы «How old is the Baikal Rift Zone? Insight from apatite fission tracк termochronology» [Jolivet et al., 2009], которую М.М. Буслов широко использует, отвечая на поставленный вопрос, заявляют о меловом возрасте Байкальского рифта. Этот вывод подкреплен рядом трековых датировок. Но это не смущает М.М. Буслова, он «прошел мимо» этого вывода и утверждает, что Байкальский рифт образовался лишь в позднем плиоцене.

Таким образом, я решительно отвергаю утверждения о плиоцен-четвертичном возрасте Байкальского рифта, так же как и попытку свести рифтовую структуру Байкальской впадины лишь к верхнему сейсмостратиграфическому комплексу. Этому противоречит огромная мощность отложений Байкальского рифта, в том числе и в Селенгинском разрезе. Как показывают несложные подсчеты, за 5 млн лет могло бы накопиться всего около 500 м осадков [Kukal, 1983]. Реальность этой цифры подтверждается данными глубоководного бурения на Байкале. Там возраст вскрытой скважиной BDP98-2 600-метровой толщи составил 8.4 млн лет [Horiuchi et al., 2004].

\section{3. БАЙКАЛЬСКИЙ РИФТ НАЧАЛ ФОРМИРОВАТЬСЯ В МИОЦЕНЕ (ПОЗДНЕМ ОЛИГОЦЕНЕ - МИОЦЕНЕ ИЛИ ОЛИГОЦЕНЕ)?}

Это наиболее широко распространенное мнение. Оно приводится и в давних работах, в том числе и в публикациях, рассматривающих результаты сейсмостратиграфических исследований [Zonenshain et al., 1995; Kaz'min et al., 1995; и дp.], и в публикациях последних лет [Mashchuk, Akulov, 2012; Rasskazov et al., 2014]. Оно основано на разрезах Южнобайкальской впадины, где на кристаллическом фундаменте залегает начинающая здесь синрифтовый разрез танхойская свита. Ее возраст - миоцен (олигоценмиоцен) - и принимается за время начала байкальского рифтогенеза. Это «танхойский феномен» - то магическое воздействие, которое производит легко наблюдаемое перекрытие фундамента рифта танхойской свитой. При изложении результатов сейсмостратиграфических работ нижний сейсмостратиграфический комплекс - ССК-1 - скоррелирован с танхойской свитой, в которую якобы и переходит 
V.D. Mats: The Baikal rift: Pliocene (Miocene) - Quaternary episode or product of extended development...

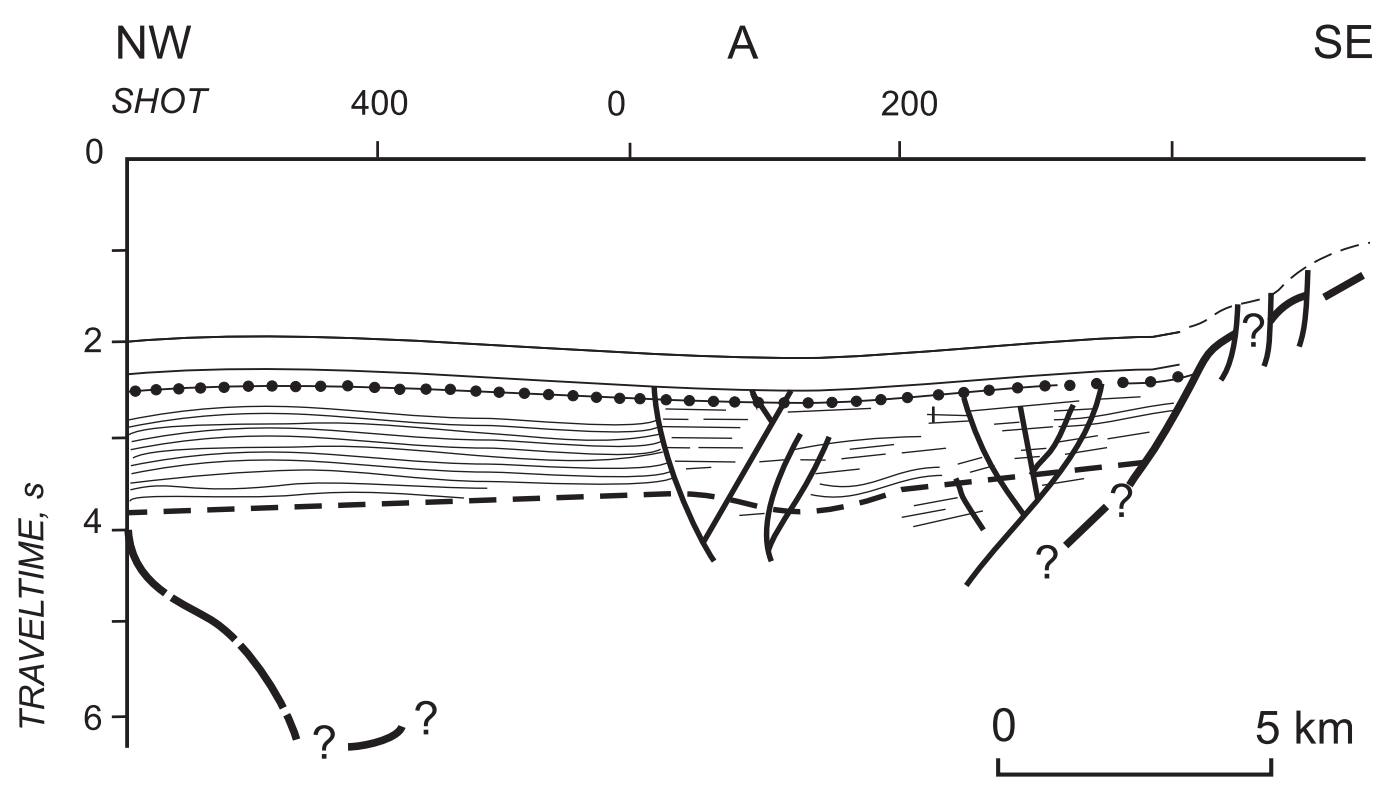

Рис. 5. Представительный профиль непрерывного сейсмического профилирования через Южный Байкал [Нutchinson et al., 1993]. На профиле видно, что ССК-1, прислоняясь к поднятию фундамента, оказывается древнее отложений (танхойская свита), обнажающихся на хамар-дабанском побережье и залегающих непосредственно на кристаллическом фундаменте.

Fig. 5. A representative profile of continuous seismic profiling across South Baikal [Hutchinson et al., 1993]. The profile shows that SSC-1, that leans against the rising slope of the basement, is older than the sediments (Tankhoi suite) that are outcropped at the Khamar-Daban shore and lay directly on the crystalline basement.

ССК-1. Соответственно определен возраст Байкальского рифта миоценом, поздним олигоценом - миоценом [Hutchinson et al., 1993; Zonenshain et al., 1995; и др.]. Однако на представительном профиле через Южнобайкальскую впадину видно, что ССК-1 не продолжается танхойской свитой, a, не доходя до береговой зоны, выпадает из разреза, прислоняясь к поднятию фундамента (рис. 5) и фундамент перекрывается вышележащим ССК-2, которому и соответствует танхойская свита. Это полностью отвечает общей закономерности строения синрифтовых комплексов, наиболее древние элементы которых остаются в глубине рифта, и на дневной поверхности фундамент перекрывают более молодые элементы синрифтового комплекса. Это эффект «несогласия растяжения» [Khain, Mikhailov, 1985].

Механизм формирования рифтового осадочного клина отчетливо виден на примере развития позднемиоценовой трансгрессии вод Среднего Байкала в Северобайкальскую впадину. Как показали сейсмостратиграфические исследования, трансгрессирующие воды проникали в Северобайкальскую впадину через понижение (подобие современного пролива Ольхонские ворота) в средней части Академического хребта [Khlystov et al., 2001; Mats et al., 2000]. В связи с общим наклоном фундамента Северобайкальской впадины к подножью хребтов, ограничивающих ее с запада - следствие листрического характера бортовых разломов, воды трансгрессии первоначально скапливались в западной части впадины. По мере возрастания водной массы фронт трансгрессии продвигался к востоку, наступая, в конечном итоге, на поднятия Академического хребта. В основании трансгрессирующей толщи формировался плащ терригенных отложений волноприбойной зоны, перекрывающих кристаллический фундамент, установленный на подводном Академическом хребте [Zonenshain et al., 1993, 1995] и на о. Ольхон, в береговых обнажениях несколько южнее мыса Саса и в бухте Харалдай (обн. 523 [Mats et al., 1982]). Наступление трансгрессирующих вод с запада на восток на подводный Академический хребет отчетливо устанавливается на сейсмостратиграфических профилях [Khlystov et al., 2000, 2001; Mats et al., 2000].

Таким образом, синрифтовая трансгрессивная толща включает нижнюю часть разреза, залегающую непосредственно на фундаменте, которая сосредоточена вдоль западного бортового разлома, и верхнюю. Последняя в прибортовой зоне залегает на нижней осадочной части, а в восточной половине Северобайкальской впадины - в районе, примыкающем к Академическому хребту, и на о. Ольхон непосредственно перекрывает кристаллический фундамент. Рассмотренный пример иллюстрирует 
теоретическую схему строения синрифтовой толщи.

Корреляция ССК-1 с танхойской свитой, предложенная Л.П. Зоненшайном и др. [Zonenshain et al., 1995], противоречит результатам структурных исследований [Delvaux et al., 1997]. ССК-1 формировался в условиях напряжений растяжения и чистого раздвига, ориентированых вкрест простирания рифта [Zonenshain et al., 1995], а танхойская моласса образовалась при напряжениях косого сжатия и косого растяжения, продуцируемых ИндоЕвроазиатским столкновением. Они ориентированы вдоль простирания рифта при господстве деформаций сдвига [Balla et al., 1990; Delvaux et al., 1997]. Таким образом, ССК-1 и танхойская свита, хотя они пространственно сближены, формировались в различных системах тектонических напряжений, что противоречит попыткам их корреляции. В то же время ССК-2 и танхойская свита формировались в однотипной системе напряжений косого сжатия и, позже (северобайкальская тектоническая фаза около 7-10 млн лет [Mats, 2012]), косого растяжения [Delvaux et al., 1997]. Корреляция ССК-1 с дотанхойским ТЛСК-1 снимает эти противоречия.

Недавно на р. Половинке (хамар-дабанское побережье), стратиграфически ниже танхойской свиты, включающей здесь известное местонахождение позднеолигоценовой-раннемиоценовой малакофауны [Popova, 1981], обнаружены алевролиты [Mats, 2013], содержащие, по заключению В.А. Мишариной и Н.В. Кулагиной, набор миоспор, сходный с палеоценовой-эоценовой флорой Сибирской платформы [Kul'kova, Laukhin, 1975], и бедные спектры миоспор растений, характерных [Pavlov et al., 1976] для палеоценовой-эоценовой каменской свиты Предбайкальского прогиба (табл. 3). Таким образом, получены хоть и фрагментарные, но прямые геологические данные о дотанхойских элементах разреза в Южнобайкальской впадине.

Из приведенного следует, что определение времени начала байкальского рифтогенеза миоценом (олигоценом, поздним олигоценом - миоценом), т.е. возрастом танхойской свиты, не соответствует известным фактам и приводит к неразрешимым противоречиям.

\section{4. БАЙКАЛЬСКИЙ РИФТ НАЧАЛ ФОРМИРОВАТЬСЯ В ПОЗДНЕМ МЕЛУ}

Впервые данные о вероятности столь древнего начала рифтогенеза были получены по результатам глубокого бурения в дельте р. Селенги. В керне четырех скважин были определены палеогеновые (эоцен) спорово-пыльцевые спектры [Faizulina,
T а б л и ц а 3. Видовой состав палиноспектра в дотанхойских алевролитах, р. Половинка. Определения Н.В. Кулагиной и В.А. Мишариной (ИЗК СО РАН)

$\mathrm{T}$ a b l e 3. Species composition of the palinospectrum of the pre-Tankhoi aleurolite samples from the area of the Polovinka river. Determined by N.V. Kulagina and V.A. Misharina (IEC SB RAS)

\begin{tabular}{|c|c|c|}
\hline Видовой состав & П-9-30-А-К & П-9-31-А-К \\
\hline \multicolumn{3}{|l|}{ Споровые: } \\
\hline Polypodiaceae & 15 & 8 \\
\hline Lycopodium sp.(плохой сохран.) & 3 & 0 \\
\hline Osmundacidites & 2 & 0 \\
\hline Sphagnum sp. & 0 & 6 \\
\hline \multicolumn{3}{|l|}{ Голосеменные: } \\
\hline Coniferae (плохой сохранности) & 2 & 0 \\
\hline Coniferae (смятые, фрагменты) & 19 & 16 \\
\hline Coniferae Piceites sp.?) Mz-J & 1 & 0 \\
\hline Picea sp. ( плохой сохранности) & 6 & 2 \\
\hline Pinus sp. & 4 & 1 \\
\hline Taxodiaceae & 1 & 0 \\
\hline Podocarpus sp. & 1 & 2 \\
\hline \multicolumn{3}{|l|}{ Покрытосеменные: } \\
\hline Triporopollenites rabustus & 6 & 0 \\
\hline Triatriapollenites plicoides & 4 & 5 \\
\hline Tricolporopollenites sp. & 0 & 7 \\
\hline Tricolpites sp. & 1 & 0 \\
\hline Comptonia sp & 5 & 7 \\
\hline Yuglandaceae & 0 & 10 \\
\hline Platycarya sp. (плохой сохран.) & 0 & 3 \\
\hline Persycarya sp. & 0 & 1 \\
\hline Carya sp. & 5 & 2 \\
\hline Ptercarya sp. ( плохой сохран.) & 3 & 0 \\
\hline Myrica sp. & 4 & 0 \\
\hline Engelhardtia sp. & 2 & 0 \\
\hline Ulmoideipites sp. (плохой сохран.) & 12 & 2 \\
\hline Ulmus sp. & 4 & 3 \\
\hline Alnus sp.(плохой сохран.) & 2 & 0 \\
\hline Betula sp. & 10 & 3 \\
\hline Corylus sp. & 9 & 1 \\
\hline Castanopsis sp. & 0 & 1 \\
\hline Ephedra sp. & 1 & 1 \\
\hline Ericales & 2 & 1 \\
\hline Compositae & 0 & 1 \\
\hline Gramineae & 2 & 1 \\
\hline Trapa sp. & 4 & 0 \\
\hline Onagraceae & 3 & 0 \\
\hline Сумма & 133 & 84 \\
\hline
\end{tabular}

Kozlova, 1966]. Соответствующие палиноспектры, полученные по параллельным разрезам, хорошо согласуются, что убеждает в том, что они in situ. Н.А. Логачев посчитал, что находки палеогена были получены при добуривании скважин [Logachev, 1974], но в других публикациях приводились иные сведения, поставившие под сомнение данные о наличии в селенгинских разрезах (в их пробуренной к тому времени части) палеогеновых отложе- 
ний. Так, в работе [Zamaraev, Samsonov, 1959] сообщалось о миоценовых палиноспектрах по разрезам (самая глубокая скважина была тогда пробурена до глубины 2558 м и не достигла фундамента) как о самых древних. В последующей публикации сообщалось, что 3.Х. Файзулиной и Е.П. Козловой выделено три горизонта: первый на глубине 3056 м, второй - 1780-1300 м и третий - 1300-630 м. Первый и третий горизонты богато охарактеризованы представительными палеогеновыми (эоцен - нижний олигоцен) палиноспектрами [Imetkhenov, 1987]. В этих сведениях вызывает удивление указание на наличие палеогена в третьем горизонте, на такой относительно незначительной глубине, ведь эта часть разреза освещена С.М. Замараевым и B.B. Самсоновым [Zamaraev, Samsonov, 1959], которые привели данные о миоценовом возрасте отложений, тогда как в интервале 1300-630 м выявлены богатые спектры палеогена [Imetkhenov, 1987]. Добавила сомнений публикация В.А. Беловой [Belo$v a, 1985]$, которая, обработав шлам скв. 4 с интервала глубин 870-960 м, обнаружила лишь пыльцевые спектры верхнего олигоцена - миоцена. Таким образом, следует признать, что действительное положение проб с палеогеновыми (эоцен - нижний олигоцен) спектрами остается неизвестным. Остается неизвестна также литология содержащих их отложений.

Тем не менее наличие палеогеновых палиноспектров (при повторении данных по нескольким скважинам) достоверно свидетельствует о наличии палеогеновых отложений в Байкальской впадине. Любые представления о возрасте Байкальского рифта должны учитывать эти данные. Максимальная глубина скважин 3100 м, при общей мощности рыхлых отложений более 5 км. Так что вполне оправдано предположение о наличии даже меловых отложений [Logachev, 1974, 2003; Mats, 1987, 2012, 2013; Mats et al., 2001].

При изучении донных отложений Байкала в них также определены палеогеновые спорово-пыльцевые спектры [Bogdanov, Zonenshain, 1991; Nikolaev, 1998]. Хотя высказаны определенные сомнения в значимости этих данных, не позволившие опереться на них при оценке возраста Байкальского рифта, так как Л.П. Зоненшайн посчитал их переотложенными [Zonenshain et al., 1995], а данные В.Г. Николаева относятся к пробам, полученным дночерпателем. Все это заставило многих отнестись скептически к полученным данным, и в большинстве публикаций, в том числе и в публикациях, основанных на сейсмостратиграфических работах [Zonenshain et al., 1995], возраст Байкальского рифта определяют возрастом танхойской свиты, что, как отмечено выше, сталкивается с непреодолимыми противоречиями.
В то же время подтверждения более значительной длительности развития Байкальской впадины приведены в работах [Nikolaev, 1998; Galazii et al., 1999; Kontorovich et al., 2007; и дp.]. Общий недостаток всех этих сведений - отсутствие данных об отложениях, содержащих столь древние растительные остатки.

Н.А. Логачев в своей последней публикации [Logachev, 2003], так же как и в более ранних работах, разделяет комплекс отложений рифтовых впадин на две части. Отложения нижней части разреза - это совокупность «...озерных, болотных и речных осадков ... палеоцена, эоцена, олигоцена и миоцена..., которая... представляет собой типичный котловинный парагенез...» [Logachev, 2003]. «Верхняя толща состоит из отложений плиоцена и четвертичного времени и отличается от нижней господством грубообломочных осадков» (Там же). Состав и строение осадочного наполнения указывают, по мнению Н.А. Логачева, на две стадии развития Байкальской зоны - стадию медленного рифтинга и стадию быстрого рифтинга.

Таким образом, несмотря на соответствующую фактическим данным оценку общей длительности формирования Байкальского рифта, Н.А. Логачев остался на той же двухстадийной модели его развития, что и ранее, не усмотрев специфику ранних этапов. На этих же позициях находятся его последователи, ученики и многие другие.

В работах [Mats, 1987, 1993, 2012, 2013; Mats et al., 2001; Mats, Perepelova, 2011; и др.] на основании комплексных геологических, в том числе литологостратиграфических, исследований рассмотрен весь разрез осадочного наполнения Байкальской впадины. Выяснены общие особенности состава отложений, и проведена корреляция разреза, обнаженного в прибрежной зоне Байкала, с сейсмостратиграфическим разрезом донных отложений и с разрезом Предбайкальского предгорного прогиба. Установлено, что разрез отложений Байкальского рифта разделяется не на два, а на три ТЛСК.

Нижний (ТЛСК-1) - каменский региональный корреляционный горизонт [Mats, 2013] - образован отложениями, коррелятными мел-палеогеновому пенеплену и состоит главным образом из высокозрелых осадков формации коры выветривания (в широком смысле), образованных в условиях субтропического (квазитропического по [Sinitsyn, 1967]) влажного климата, и сложен преимущественно мономиктовыми мелкоземистыми продуктами плоскостного смыва латерит-каолинитовой коры выветривания, покрывавшей пенеплен. Реликты этого пенеплена и коры выветривания сохранились в современном рельефе. Реликты отложений волноприбойной зоны озера представлены кварц-кварцитовыми отложениями, приме- 
ром которых служат кварц-кварцитовые гравий и мелкие гальки, перемытые в состав современных пляжей бухт Песчаной, Бабушки и др. В сейсмостратиграфическом разрезе им соответствует ССК-1 - прозрачный сейсмический комплекс.

В полной мере эти литологические особенности выражены в отложениях Предбайкальского прогиба, в субаэральных фациях Байкальской впадины, в отложениях малых озер и в древних речных долинах Западного Прибайкалья [Mats, Yefimova, 2010, 2011; Granina et al., 2010]. Собственно фации древнейших элементов рифтовых озер Байкальской впадины остаются малоизвестными, так как скрыты в глубинном разрезе рифта. Но очевидно, что такое огромное осадочное тело не может состоять только из продуктов плоскостного смыва пенеплена. К ним обязательно прибавлялись полиолигомиктовые продукты эрозии. Ведь эпоха пенепленизации, продолжавшаяся около 40 млн лет, прерывалась моментами оживления вертикальных тектонических движений.

Этот комплекс отложений - продукт уникальной природной обстановки, не повторявшейся в более поздние времена, поэтому их литолого-формационная корреляция с отложениями позднего мела - раннего олигоцена Предбайкальского прогиба вполне надежна и позволяет определить геологический возраст ТЛСК-1 и ССК-1.

Рифтовая впадина образовалась на фоне пенеплена (щелевой рифт по Е.Е. Милановскому) в виде одностороннего грабена, формировавшегося по схеме чистого раздвига при ориентировке растягивающих напряжений с северо-запада на юго-восток вкрест простирания рифта по азимуту 145$150^{\circ}$ [Zonenshain et al., 1995]. Впадина выполнена ССК-1. С северо-запада она ограничена листрическим сбросом, к которому примыкают депоцентры ССК-1 (см. рис. 2). Рифтогенез на этом этапе проходил по пассивной модели, до начала Индо-Евроазиатского столкновения [Mats, 2012; Mats, Perepelova, 2011].

Средний комплекс Байкальского рифта (ТЛСК-2), типичным представителем которого являются отложения танхойского горизонта, сложен существенно полимиктовыми мелкоземистыми, преимущественно озерными, отложениями (алевролиты, прослои угля - танхойская свита [Mats et al., 2001; Mats, 2013; Mashchuk, Akulov, 2012; Rasskazov et al., 2014]), фациально замещающимися грубообломочными аллювиальными и прибрежно-озерными отложениями - осиновская свита [Mats, 1985, 2013]. Осадки образовывались в позднем олигоцене - раннем миоцене при влажном субтропическом климате, а с середины миоцена - в условиях сухих субтропиков при климате, близком к средиземноморскому [Vorob'eva et al., 1995]. Это продукты эрозионного раз- мыва начавшего воздыматься Байкальского свода, по своей формационной характеристике соответствующие типичной нижней молассе. В сейсмостратиграфическом разрезе ей соответствует ССК-2 слоистый деформированный комплекс.

Структуры Байкальского рифта на этом этапе формировались под воздействием транспрессии, а позднее транстенсии, продуцируемых Индо-Евроазиатским столкновением. Вектор напряжений развернулся относительно вектора, продуцировавшего CCК-1, против часовой стрелки в направлении CBЮ3 субпараллельно Байкальскому рифту [Delvaux et al., 1997; Zonenshain et al., 1995]. Это определено как для времени формирования ССК-2 [Zonenshain et al., 1995], так и для танхойского времени [Delvaux et al., 1997]. Структура рифта была преобразована в двухсторонний грабен, ограниченный листрическими сбросами [Hutchinson et al., 1993; Zonenshain et al., 1995; Kaz'min et al., 1995]. Обстановка косого сжатия и растяжения вызвала активное сдвигообразование [Balla et al., 1990; Delvaux et al., 1997; Parfeevets, San'kov, 2006] и обусловила деформационную структуру ССК-2. Отмеченные изменения согласуются с северо-восточным направлением напряжений, передаваемых фронтом Индо-Евроазиатской коллизии, который к этому времени - вторая половина олигоцена - миоцен - достиг Байкальского региона. Байкальский рифт развивался под воздействием процессов на границах плит по импактогенной модели.

Верхний комплекс (ТЛСК-3) сложен грубообломочными отложениями и песками шанхаихинского (аносовского) и нюрганского корреляционных горизонтов [Mats, 2013] - продуктами размыва Байкальского свода, временами покрывавшегося ледниками. Климат в дочетвертичной части этого времени оставался сходным с климатом Средиземноморья, а в четвертичное время был умеренным с различной степенью увлажненности, а периодически нивальным [Vorob'eva et al., 1995].

Характерным элементом разрезов среднемиоцен-плиоценовых отложений «заторможенных» блоков Байкальского рифта, например Ольхонского, является красноцветная формация [Logachev, 1974; u $\partial p$.], состав которой уточнен впоследствии [Mats et al., 1982; Mats, 2013]. Она включает два горизонта - нижний миоцен - нижнеплиоценовый («red clay») и верхнеплиоценовый («redishe clay»), охарактеризованные обильной ископаемой фауной моллюсков и млекопитающих [Mats et al., 1982; Pokatilov, 1985; Popova, 1981; Popova et al., 1989].

Рифтовая структура ССК-3 вновь формировалась под воздействием чистого раздвига, ориентированного СЗ-ЮВ, образовался односторонний грабен [Zonenshain et al., 1995]. Рифтогенез проходил по активной модели под воздействием воздымаю- 
V.D. Mats: The Baikal rift: Pliocene (Miocene) - Quaternary episode or product of extended development...

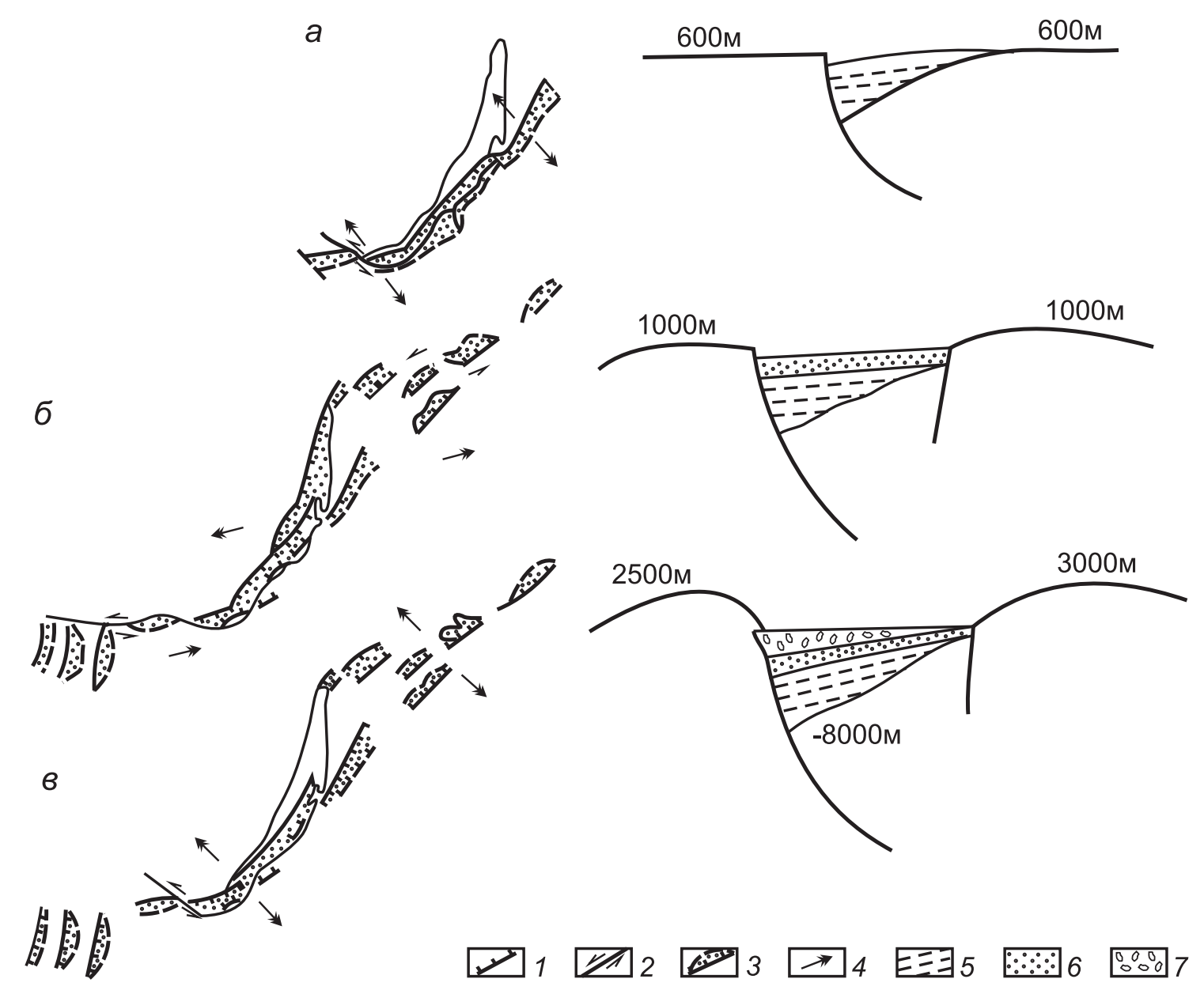

Рис. 6. Этапы развития Байкальской рифтовой зоны ([Mats, 2012] из [Zonenshain et al., 1995], с изменениями и дополнениями).

$a$ - ССК-1 - поздний мел - ранний олигоцен; б - ССК-2 - поздний олигоцен - ранний плиоцен; 8 - ССК-3 - поздний плиоцен квартер. 1 - активные сбросы; 2 - сдвиги; 3 - активные грабены; 4 - направление раздвига; 5-7 - формации: 5 - коры выветривания (преимущественно мономиктовые продукты переотложения латерит-каолинитовой коры выветривания), 6 - нижнемолассовая (полимиктовые, преимущественно мелкоземистые отложения), 7 - верхнемолассовая (полимиктовые, преимущественно грубообломочные отложения); 600 м - высота над уровнем моря.

Fig. 6. Development stages of the Baikal rift zone ([Matz, 2012] from [Zonenshain et al., 1995], with amendments and additions).

$a$ - SSC-1 (Late Cretaceous - Early Oligocene); 6 - SSC-2 (Late Oligocene - Early Pliocene); 8 - SSC-3 (Late Pliocene - Quarter). 1 - active normal faults; 2 - strike-slip faults; 3 - active graben; 4 - direction of expansion; 5-7 - rock formations: 5 - weathering crust (mainly monomict products of redeposited laterite-kaolinite weathering crust), 6 - Lower Molasse (polymictic, mainly earthy deposits), 7 - Upper Molasse (polymictic, mainly coarse deposits); $600 \mathrm{~m}$ - elevation.

щегося глубинного плюма [Zorin, Turutanov, 2005; Logachev, Zorin, 1987; Zorin et al., 2003]. Растяжение не прерывалось сжатием, и осадочная толща ССК-3 не деформирована.

\section{5. ЗАКЛЮЧЕНИЕ}

Анализ геологической истории Байкальского рифта показывает, что представление о его формировании в позднеплиоценовое - четвертичное время противоречит всем известным геолого-гео- физическим данным и его следует снять с обсуждения. Утверждения о его образовании в миоцен (поздний олигоцен) - четвертичное время также не соответствуют имеющимся реальным геологическим и геофизическим данным. Лишь признание начала рифтогенеза в позднем мелу позволяет понять его во всем разнообразии и сложности процесса.

Корреляция разрезов на околобайкальском сухопутье с синрифтовым сейсмостратиграфическим разрезом донных отложений Байкальской впадины и с разрезом Предбайкальского предгорного про- 
гиба позволила определить синрифтовый характер разреза на окружающей Байкал суше и возраст элементов сейсмостратиграфического разреза. Признание мелового возраста Байкальского рифта и его комплексное геологическое изучение позволили обосновать новый взгляд на процессы его формирования во всей их сложности и многообразии [Mats, 1987, 1993, 2011, 2012, 2013; Mats, Perepelova, 2011; Mats et al., 1982, 2000, 2001, 2004; $u$ dp.].

Новые аргументы, подтверждающие древность Байкальской впадины, представлены в работах [Logachev, 2003; Nikolaev, 1998; Galazii et al., 1999; Kontorovich et al., 2007; Shcherbakov, 2003; Jolivet et al., 2009].

Таким образом, в итоге многолетних комплексных исследований была предложена модель трехэтапного развития Байкальского рифта (рис. 6), противостоящая общепринятой двухэтапной модели и общепринятые пассивная и активная модели рифтогенеза дополнены импактогенной моделью [Mats, 2012; Mats, Perepelova, 2011].

На первом этапе - поздний мел - ранний олигоцен (70-30 млн лет) - рифт формировался в условиях общего рассеянного растяжения литосферы и ее высокой проницаемости для глубинных эманаций, при отсутствии высокогорных преград, общем смещении к северу широтных поясов, что определило смещение к северу растительных зон и малакофауны [Tsekhovsky et al., 1996a, 1996b; Devyatkin, 1981; Kuzmin, Yarmolyuk, 2006; Martinson, 1998; Volkova, Kuz'mina, 2005]. Все это имело место до проникновения в Байкальский регион напряжений, продуцируемых Индо-Евроазиатским столкновением.

Рассеянное растяжение в древних ослабленных зонах - зонах глубинных разломов - трансформировалось в напряжения растяжения, ориентиро- ванные вкрест простирания этих зон, что приводило к формированию рифтов. Пример такого хода событий дает картина распределения рифтов в фундаменте Русской платформы [Milanovskii, 1976].

В Байкальском регионе под воздействием растягивающих напряжений, ориентированных в СЗ-ЮВ направлении в зоне разломов краевого шва Сибирской платформы, по пассивной модели сформировались рифтовые односторонние впадины, ограниченные с запада листрическими разломами.

На втором этапе - поздний олигоцен - ранний плиоцен (30-5 млн лет) - рифт развивался под воздействием напряжений, продуцируемых ИндоЕвроазиатским столкновением, и проходил по импактогенной модели. Вектор напряжений, действовавший в зоне рифта на первом этапе, на втором этапе был повернут по часовой стрелке и ориентирован в Ю3-СВ направлении [Zonenshain et al., 1995; Delvaux et al., 1997]. Под воздействием напряжений, касательных к простиранию рифта, сформировались двухсторонние грабены, ограниченные листрическими сбросами. Основное значение имели деформации сдвига. Растяжение временами сменялось сжатием (Северобайкальская и Ольхонская тектонические фазы), что привело к деформации осадочной толщи ССК-2 и ТЛСК-2.

На третьем этапе - поздний плиоцен - квартер (5 млн лет - современность) - рифт развивался под воздействием местных источников напряжений, по активной модели. Сформировались односторонние грабены, ограниченные с запада листрическими разломами. Растягивающие напряжения были вновь ориентированы СЗ-ЮВ. Растяжение не прерывалось сжатием, и осадочная толща третьего этапа сохраняет первичное залегание.

\section{6. ЛИТЕРАТУРА / REFERENCES}

Artyushkov E.V., 1993. Physical Tectonics. Nauka, Moscow, 456 p. (in Russian) [Артюшков Е.В. Физическая тектоника. М.: Наука, 1993. 456 с.].

Balla Z., Kuzmin M.I., Levi K.G., 1990. Kinematics of the Baikal opening. Geotektonika (Geotectonics) (2), 80-91 (in Russian) [Балла 3., Кузьмин М.И., Леви К.Г. Кинематика раскрытия Байкала // Геотектоника. 1990. № 2. C. 80-91].

Bazarov D.-D.B., 1986. Cenozoic of Baikal Region and Western Transbaikalia. Nauka, Novosibirsk, 181 p. (in Russian) [Базаров Д.-Д.Б. Кайнозой Прибайкалья и Западного Забайкалья. Новосибирск: Наука, 1986. 181 с.].

Belova V.A., 1985. Vegetation and Climate of the Late Cenozoic of the south of Eastern Siberia. Nauka, Novosibirsk, 160 p. (in Russian) [Белова В.A. Растительность и климат позднего кайнозоя юга Восточной Сибири. Новосибирск: Наука, 1985. 160 с.].

Bogdanov Yu.F., Zonenshain L.P., 1991. Outcrops of the Miocene sediments at the bottom of Lake Baikal and timing of normal faulting (based on observations from 'Pisces' submersibles). Doklady AN SSSR 320 (4), 931-933 (in Russian) [Богданов Ю.Ф., Зоненшайн Л.П. Обнажения миоценовых осадков на дне озера Байкал и время сбросообразования (по наблюдениям с подводных обитаемых аппаратов «Пайсис» // Доклады АН СССР. 1991. T. 320. № 4. C. 931-933].

Buslov M.M., 2012. Geodynamic nature of the Baikal Rift Zone and its sedimentary filling in the Cretaceous-Cenozoic: the effect of the far-range impact of the Mongolo-Okhotsk and Indo-Eurasian collisions. Russian Geology and Geophysics 53 (9), 955-962. http://dx.doi.org/10.1016/j.rgg.2012.07.010. 
Delvaux D., Moyes R., Stapel G., Petit C., Levi K., Miroshnichenko A., Ruzhich V., San'kov V., 1997. Paleostress reconstruction and geodynamics of the Baikal region, Central Asia, Part 2. Cenozoic rifting. Tectonophysics 282 (1-4), 1-38. http://dx.doi.org/10.1016/S0040-1951(97)00210-2.

Devyatkin E.V., 1981. Cenozoic of Inner Asia (Stratigraphy, Geochronology, Correlation). Nauka, Moscow, 196 p. (in Russian) [Девяткин E.B. Кайнозой Внутренней Азии (стратиграфия, геохронология, корреляция). М.: Наука, 1981.196 c.]

Dombrovskaya Zh.V., 1973. Paleogene Weathering Crust of the Central Baikal Region. Nauka, Moscow, 155 p. (in Russian) [Домбровская Ж.В. Палеогеновая кора выветривания Центрального Прибайкалья. М.: Наука, 1973. 155 с.].

Faizulina Z.Kh., Kozlova E.P., 1966. Results of the palinological study of the Tertiary sediments cut by deep drilling. In: Geology and oil-bearing capacities of East Siberia. Nedra, Moscow, p. 362-366 (in Russian) [Файзулина 3.X., Козлова Е.П. Результаты палинологического изучения третичных отложений, вскрытых глубоким бурением // Геология и нефтегазоносность Восточной Сибири. М.: Недра, 1966. С. 362-366].

Florensov N.A., 1960. Mezosoic and Cenozoic Depressions of the Baikal Region. USSR Academy of Sciences Publishing House, Moscow-Leningrad, 258 p. (in Russian) [Флоренсов H.A. Мезозойские и кайнозойские впадины Прибайкалья. М.-Л.: Изд-во АН СССР, 1960. 258 с.].

Galazii G.I., Kuz'min M.I., Lut B.F., 1999. Age of the Baikal basin: implications from estimates of the particulate and dissolved inputs. Geografiya i Prirodnye Resursy (Geography and Natural Resources) (1), 10-15 (in Russian) [Галазий Г.И., Кузьмин М.И., Лут Б.Ф. О возрасте впадины Байкала (на основе оценки поступающего в нее взвешенного и растворенного вещества // География и природные ресурсы. 1999. № 1. С. 10-15].

Geologic Time Scale, 2008. Available from: http://www.stratigraphy.org (last accessed November 18, 2015).

Granina L.Z., Mats V.D., Phedorin M.A., 2010. Iron-manganese formations in the Baikal region. Russian Geology and Geophysics 51 (6), 650-660. http://dx.doi.org/10.1016/j.rgg.2010.05.006.

Horiuchi K., Goldberg E.L., Matsuzaki H., Kobayashi K.K., Shibata Y., 2004. ${ }^{10}$ Be signature in the Miocene section of BDP cores (Lake Baikal): testing magnetostratigraphic age models. Geologiya i Geofizika (Russian Geology and Geophysics) 45 (3), 408-412.

Hutchinson D.R., Gol'mshtok A.Yu., Zonenshain L.P., Moore T., Scholz C., Klitgord K.D., 1993. Preliminary results from 1989 multichannel seismic reflection survey in Lake Baikal. Geologiya i Geofizika (Russian geology and geophysics) 34 (10-11), 25-36 (in Russian) [Хатчинсон Д.Р., Гольмшток А.Ю., Зоненшайн Л.П., Мур Т.К., Шольц К.А., Клитгорд К.Д. Особенности строения осадочной толщи оз. Байкал по результатам многоканальной сейсмической съемки (1989) // Геология и геофизика. 1993. Т. 34. № 10-11. С. 25-36].

Imetkhenov A.B., 1987. Late Cenozoic Deposits on the Baikal Lake Shore. Nauka, Novosibirsk, 150 p. (in Russian) [Иметхенов А.Б. Позднекайнозойские отложения побережья озера Байкал. Новосибирск: Наука, 1987. 150 c.].

Jolivet L., De Boisgrollier T., Petit C., Fournier M., San'kov V.A., Ringenbach J.-C., Byzov L., Miroshnichenko A.I., Kovalenko S.N., Anisimova S.A., 2009. How old is the Baikal Rift Zone? Insight from apatite fission trac termochronology. Tectonics 28 (3), TC3008. http://dx.doi.org/10.1029/2008TC002404.

Kaz'min V.G., Gol'mshtok A.Ya., Klitgord K.D., Moore T., Hutchinson D., Scholz C., Weber E., 1995. Structure and development of the Akademichesky Ridge area (Baikal Rift) according to seismic investigations. Geologiya i Geofizika (Russian Geology and Geophysics) 36 (10), 164-176 (in Russian) [Казьмин В.Г., Гольмшток А.Я., Клитгорд К., Мур Т., Хатчинсон Д., Шольи С., Вебер E. Строение и развитие района Академического хребта по данным сейсмических и подводных исследований (Байкальский рифт) // Геология и геофизика. 1995. Т. 36. № 10 C. 164-176].

Khain V.E., Mikhailov A.E., 1985. General Geotectonics. Nedra, Moscow, 326 p. (in Russian) [Хаин B.E., Михайлов A.E. Общая геотектоника. М.: Недра, 1985. 326 с.].

Khlystov O.M., Mats V.D., De Batist M., 2001. The southwestern edge of the North Baikal basin: Geologic structure and correlation with Cenozoic sections of Ol'khon and BDP-96 and BDP-98 cores. Geologiya i Geofizika (Russian Geology and Geophysics) 42 (1-2), 373-383.

Khlystov O.M., Mats V.D., Vorob'eva S.S., Klimanskii A.V., De Batist M., Ceramicola S., 2000. Structure and evolution of the underwater Akademichesky Ridge (Lake Baikal). Geologiya i Geofizika (Russian Geology and Geophysics) 41 (6), 819-824.

Kontorovich A.E., Kashirtsev V.A., Moskvin V.I., Burshtein L.M., Zemskaya T.I., Kostyreva E.A., Kalmychkov G.V., Khlystov O.M., 2007. Petroleum potential of Baikal deposits. Russian Geology and Geophysics 48 (12), 1046-1053. http://dx.doi.org/10.1016/j.rgg.2007.11.004.

Kozhov M.M., 1972. Essays on Lake Baikal. East-Siberian Publishing House, Irkutsk, 254 p. (in Russian) [Кожов М.М. Очерки по байкаловедению. Иркутск: Вост.-Сиб. кн. изд-во, 1972. 254 с.].

Krasnov E.V. (Ed.), 1987. Geosynclinal Lithogenesis on the Continent - Ocean Boundary. Nauka, Moscow, 175 p. (in Russian) [Геосинклинальный литогенез на границе континент - океан / Ред. Е.В. Краснов. М.: Наука, 1987. 175 c.].

Kukal Z., 1983. Rychlost geologických procesů. Academia, Praha, 280 s. (in Czech) [Кукал 3. Скорость геологических процессов: Пер. с чешского. М.: Мир, 1987. 246 с.]

Kul'kova I.A., Laukhin S.L., 1975. Palynology of Paleogene bauxite deposits in the Yenisei Kryazh. In: V.S. Volkova (Ed.), Cenozoic palynology of Siberia. Nauka, Novosibirsk, p. 11-26 (in Russian) [Кулькова И.А., Лаухин С.Л. Палиноло- 
гия палеогеновых бокситоносных отложений Енисейского кряжа // Палинология кайнозоя в Сибири / Ред. В.С. Волкова. Новосибирск: Наука, 1975. С. 11-26].

Kuz'min M.I., Karabanov E.B., Kawai T., Williams D., Bychinsky V.A., Kerber E.V., Kravchinsky V.A., Bezrukova E.V., Prokopenko A.A., Geletii V.F., Kalmychkov G.V., Goreglyad A.V., Antipin V.S., Khomutova M.Yu., Soshina M.N., Ivanov E.V., Khursevich G.K., Tkachenko L.L., Solotchina E.P., Ioshida N., Gvozdkov A.N., 2001. Deep drilling on Lake Baikal: main results. Geologiya i Geofizika (Russian Geology and Geophysics) 42 (1-2), 6-32.

Kuzmin M.I., Yarmolyuk V.V., 2006. Mountain growth and climatic variations in the Earth's history. Geologiya i Geofizika (Russian Geology and Geophysics) 47 (1), 4-20.

Lamakin V.V., 1968. Neotectonics of the Baikal Basin. Nauka, Moscow, 247 p. (in Russian) [Ламакин В.B. Неотектоника Байкальской впадины. М.: Наука, 1968. 247 с.].

Logachev N.A., 1958. Cenozoic continental deposits in Baikal type basins. Izvestiya AN SSSR. Seriya geologicheskaya (4), 18-29 (in Russian) [Логачев Н.A. Кайнозойские континентальные отложения впадин байкальского типа // Известия АН СССР. Серия геологическая. 1958. № 4. С. 18-29].

Logachev N.A., 1968. Sedimentary and volcanic formation of Baikal Rift Zone. In: N.A. Florensov (Ed.), Baikal rift. Nauka, Moscow, p. 72-101 (in Russian) [Логачев H.A. Осадочные и вулканогенные формации Байкальской рифтовой зоны // Байкальский рифт / Ред. Н.А. Флоренсов. М.: Наука, 1968. С. 72-101].

Logachev N.A., 1974. Sayan-Baikal Stanovoi Uplift. In: N.A. Florensov (Ed.), Uplifts of Pre-Baikalian and Transbaikalian Regions. Nauka, Moscow, p. 16-162 (in Russian) [Логачев Н.A. Саяно-Байкальское Становое нагорье // Нагорья Прибайкалья и Забайкалья / Ред. Н.А. Флоренсов. М.: Наука, 1974. С. 16-162].

Logachev N.A., 2003. History and geodynamics of the Baikal rift. Geologiya i geofizika (Russian Geology and Geophysics) 44 (5), 391-406.

Logachev N.A., Zorin Yu.A., 1987. Evidence and causes of the two-stage development of the Baikal rift. Tectonophysics 143 (1-3), 225-234. http://dx.doi.org/10.1016/0040-1951(87)90092-8.

Martinson G.G., 1951. Tertiary fauna of mollusks in Eastern Pribaikalie. In: Proceedings of the Baikal Limnological Station of the USSR Academy of Sciences. Vol. XIII. Publishing House of the USSR Academy of Sciences, Moscow, p. 592 (in Russian) [Мартинсон Г.Г. Третичная фауна моллюсков Восточного Прибайкалья // Труды Байкальской лимнологической станции АН СССР. Т. ХІІІ. М.: Изд-во АН СССР, 1951. С. 5-92].

Martinson G.G., 1998. Paleogene stage of evolution of the largest lacustrine basins of Northeastern Asia and of continental deposits of nonmarine mollusks. Geologiya i Geofizika (Russian Geology and Geophysics) 39 (3), 279-286.

Mashchuk I.M., Akulov N.I., 2012. Oligocene deposits of the Baikal rift valley. Russian Geology and Geophysics 53 (4), 356-366. http://dx.doi.org/10.1016/j.rgg.2012.02.012.

Mats V.D., 1985. New data on Miocene and Pliocene stratigraphy of Southern Baikal. In: N.A. Florensov (Ed.), Geology and Paleogeography of Siberia and the Far East. Irkutsk state university Publishing House, Irkutsk, p. 36-53 (in Russian). [Mац В.Д. Новые данные по стратиграфии миоценовых и плиоценовых отложений на юге Байкала // Вопросы геологии и палеогеографии Сибири и Дальнего Востока / Ред. Н.А. Флоренсов. Иркутск: Изд-во ИГУ, 1985. С. 36-53].

Mats V.D., 1987. The Baikal Basin in the Cenozoic. Synopsis of the thesis, PhD in Geology and Mineralogy. Irkutsk, 42 p. (in Russian) [Mац В.Д. Кайнозой Байкальской впадины: Автореф. дис. ... докт. геол.-мин. наук. Иркутск, 1987. 42 c.].

Mats V.D., 1993. The structure and development of the Baikal rift depression. Earth-Science Reviews 34 (2), 81-118. http://dx.doi.org/10.1016/0012-8252(93)90028-6.

Mats V.D., 2011. Geological factors in the formation of unique biodiversity in Baikal ecosystem. In: O.A. Timoshkin (Ed.), Index of animal species inhabiting Lake Baikal and its catchment area. Vol. II. Basins and channels in the south of East Siberia and North Mongolia, Book 2. Nauka, Novosibirsk, p. 1406-1419 (in Russian) [Mau В.Д. Геологические факторы формирования уникального биоразнообразия Байкала // Аннотированный список фауны озера Байкал и его водосборного бассейна T. II. Водоемы и водотоки юга Восточной Сибири и Северной Монголии, Книга 2 / Ред. О.А. Тимошкин. Новосибирск: Наука, 2011. С. 1406-1419].

Mats V.D., 2012. The sedimentary fill of the Baikal Basin: Implications for rifting age and geodynamics. Russian Geology and Geophysics 53 (9), 936-954. http://dx.doi.org/10.1016/j.rgg.2012.07.009.

Mats V.D., 2013. Late cretaceous and cenozoic stratigraphy of the Baikal Rift sediments. Stratigraphy and Geological Correlation 21 (6), 637-651. http://dx.doi.org/10.1134/S0869593813060075.

Mats V.D., Khlystov O.M., De Batist M., Ceramicola S., Lomonosova T.K., Klimansky A.V., 2000. Evolution of the Academician Ridge accommodation zone in the central part of the Baikal Rift, from high-resolution reflection seismic profiling and geological field investigation. International Journal of Earth Sciences 89 (2), 229-250. http://dx.doi.org/10.1007/s005310000094.

Mats V.D., Lomonosova T.K., Vorobyova G.A., Granina L.Z., 2004. Upper Cretaceous - Cenozoic clay minerals of the Baikal region (Eastern Siberia). Applied clay science 24 (3-4), 327-336. http://dx.doi.org/10.1016/j.clay.2003.08.008.

Mats V.D., Perepelova T.I., 2011. A new perspective on evolution of the Baikal Rift. Geoscience Frontiers 2 (3), 349-365. http://dx.doi.org/10.1016/j.gsf.2011.06.002.

Mats V.D., Pokatilov A.G., Popova S.M., Kravchinsky A.Ya., Kulagina N.V., Shimaraeva M.K., 1982. The Pliocene and Pleistocene of Middle Baikal. Nauka, Novosibirsk, 192 p. (in Russian) [Мац В.Д., Покатилов А.Г., Попова С.М., Кравчинский А.Я., Кулагина Н.В., Шимараева М.К. Плиоцен и плейстоцен Среднего Байкала. Новосибирск: Наука, 1982. 192 с.]. 
Mats V.D., Ufimtsev G.F., Mandel'baum M.M., Alakshin A.M., Pospeev A.V., Shimaraev M.N., Khlystov O.M., 2001. The Baikal Basin in the Cenozoic: Structure and Geologic History. Siberian Branch of RAS Publishing House, Filial "Geo", Novosibirsk, 252 p. (in Russian) [Мац В.Д., Уфимцев Г.Ф., Мандельбаум М.М., Алакшин А.М., Поспеев А.В., Шимараев М.Н., Хлыстов О.М. Кайнозой Байкальской рифтовой впадины: строение и геологическая история. Новосибирск: Изд-во СО РАН, филиал «Гео», 2001. 252 с.].

Mats V.D., Yefimova I.M., 2010. Morphostructure of the west shoulder of the Baikal rift. Geomorfologiya (Geomorphology) (1), 67-76 (in Russian) [Мац В.Д., Ефимова И.М. Морфоструктура западного поднятого плеча Байкальского рифта // Геоморфология. 2010. № 1. С. 67-76].

Mats V.D., Yefimova I.M., 2011. Paleogeographic scenario of the Late Cretaceous - Cenozoic for the central part of the Baikal region. Geodynamics \& Tectonophysics 2 (2), 175-193 (in Russian) [Мац В.Д., Ефимова И.М. Палеогеографический сценарий позднего мела - кайнозоя центральной части Байкальского региона // Геодинамика и тектонофизика. 2011. Т. 2. № 2. C. 175-193]. http://dx.doi.org/10.5800/GT-2011-2-2-0040.

Milanovskii E.E., 1976. Rift Zones of Continents. Nedra, Moscow, 277 p. (in Russian) [Милановский Е.Е. Рифтовые зоны континентов. М.: Наука, 1976. 277 с.].

Moore T.C., Klitgord K.D., Golmstok A.Ya., Weber E., 1997. Sedimentation and subsidence patterns in the central and north basins of Lake Baikal from seismic stratigraphy. Geological Society of America Bulletin 109 (6), 746-766. http://dx.doi.org/10.1130/0016-7606(1997)109<0746:SASPIT>2.3.CO;2.

Nikolaev V.G., 1998. Age of origin of the Baikal basin. Bulletin of Moscow Society of Naturalists, Geological section 73 (4), 13-16 (in Russian) [Николаев В.Г. О времени заложения Байкальской впадины // Бюллетень Московского общества испытателей природы. Отдел геологический. 1998. Т. 73. Вып. 4. С. 13-16].

Nikolaev V.G., Vanyakin L.A., Kalinin V.V., Milanovskii V.E., 1985. The structure of the sedimentary cover of Lake Baikal. Bulletin of Moscow Society of Naturalists, Geological section 60 (2), 48-58 (in Russian) [Николаев В.Г., Ванякин Л.А., Калинин В.В., Милановский В.Е. Строение осадочного чехла озера Байкал // Бюллетень Московского общества испытателей природы. Отдел геологический. 1985. Т. 60. Вып. 2. С. 48-58].

Parfeevets A.V., San'kov V.A., 2006. Stress State of the Earth's Crust and Geodynamics of the Southwestern Part of the Baikal Rift System. Academic Publishing House "Geo", Novosibirsk, 151 p. (in Russian) [Парфеевец А.В., Саньков В.A. Напряженное состояние земной коры и геодинамика юго-западной части Байкальской рифтовой системы. Новосибирск: Академическое изд-во «Гео», 2006. 151 с.].

Pavlov S.F., Kashik S.A., Lomonosova T.K., Klimanova V.M., 1976. Cenozoic Weathering Profiles and Sedimentary Sequences of the Western Baikal Region. Nauka, Novosibirsk, 160 c. (in Russian) [Павлов С.Ф., Кашик C.A., Ломоносова Т.К., Климанова В.М. Кайнозойские коры выветривания и осадочные формации Западного Прибайкалья. Новосибирск: Наука, 1976. 160 с.].

Pleshanov S.P., Romazina A.A., 1981. Some questions of the fault kinematics in the central part of the Baikal Rift. In: N.A. Logachev, S.I. Sherman (Eds.), Problems of Fault Tectonics. Nauka, Novosibirsk, p. 129-141 (in Russian) [Плешанов С.П., Ромазина А.А. Некоторые вопросы кинематики развития разломов центральной части Байкальского рифта // Проблемы разломной тектоники / Ред. Н.А. Логачев, С.И. Шерман. Новосибирск: Наука, 1981. С. 129-141].

Pokatilov A.G., 1985. Geology and paleontology of Late Cenozoic deposits in the Baikal region. Izvestiya AN SSSR. Seriya geologicheskaya (9), 52-64 (in Russian) [Покатилов А.Г. Геология и фауна позднекайнозойских отложений в Прибайкалье // Известия АН СССР. Серия геологическая. 1985. № 9. С. 52-64].

Popova S.M., 1981. Cenozoic Continental Malacofauna in Southern Siberia and Adjacent Regions. Nauka, Moscow 178 p. (in Russian) [Попова C.M. Кайнозойская континентальная малакофауна юга Сибири и сопредельных стран. М.: Наука, 1981.178 с.].

Popova S.M., Mats V.D., Chernyaeva G.P., 1989. Baikal Rift Zone: Paleolimnological Reconstructions. Nauka, Novosibirsk, 111 p. (in Russian) [Попова С.M., Мац В.Д., Черняева Г.П. Палеолимнологические реконструкции. Байкальская рифтовая зона. Новосибирск: Наука, 1989. 111 с.]

Rasskazov S.V., Lyamina N.A., Luzina I.V., Chernyaeva G.P., Chuvashova I.S., Usoltseva M.V., 2014. Sediments in the Tertiary Tankhoi field, South Baikal basin: stratigraphy, correlation and structural transformations in the Baikal region. Geodynamics \& Tectonophysics 5 (4), 993-1032 (in Russian) [Рассказов С.В., Лямина Н.А., Лузина И.В., Черняева Г.П., Чувашова И.С., Усольцева М.В. Отложения Танхойского третичного поля, Южнобайкальская впадина: стратиграфия, корреляция и структурные перестройки в Байкальском регионе // Геодинамика и тектонофизика. 2014. T. 5. № 4. C. 993-1032]. http://dx.doi.org/10.5800/GT-2014-5-4-0165.

San'kov V.A., Miroshnichenko A.I., Levi K.G., Lukhnev A.V., Melnikov A.I., Delvaux D., 1997. Cenozoic stress field evolution in the Baikal rift zone. Bulletin du Centre de Recherches Elf Exploration Production 21 (2), 435-455.

Shcherbakov Yu.D., 2003. Comparative Study of Evolution Histories of Baikal Invertebrata Species. Synopsis of the Thesis, PhD in Biology. Zoological Institute RAS, St. Petresburg, Moscow, 39 p. (in Russian) [Щербаков Ю.Д. Сравнительное исследование эволюционных историй букетов видов байкальских беспозвоночных: Автореф. дис. ... докт. биол. наук. СПб.-М.: ЗИН РАН, 2003. 39 с.].

Sinitsyn V.M., 1967. Introduction to Paleoclimatology. Nedra, Leningrad, 232 p. (in Russian) [Синицын В.М. Введение в палеоклиматологию. Л.: Недра, 1967. 232 с.].

Tsekhovsky V.V., Muraviev V.I., Muzylev N.G., Akhmetiev M.A., 1996a. The Early Cenozoic sedimentation at ancient and young platforms of the central part of Eurasia in conditions of the crust extension and terrain peneplenization. Article 1. Paleogeography and volcanism. Bulletin of Moscow Society of Naturalists. Geological Section 71 (1), 14-25 (in Russian) [Цеховский Ю.Г., Муравьев В.И., Музылев Н.Г., Ахметьев М.А. Раннекайнозойское осадконакоп- 
ление на древних и молодых платформах центральной части Евразии в обстановках растяжения земной коры и пенепленизации рельефа. Статья 1. Палеогеография и вулканизм // Бюллетень Московского общества испытателей природы. Отдел геологический. 1996. Т. 71. Вып. 1. С. 14-25].

Tsekhovsky V.V., Muraviev V.I., Muzylev N.G., Akhmetiev M.A., 1996b. The Early Cenozoic sedimentation at ancient and young platforms of the central part of Eurasia in conditions of the crust extension and terrain peneplenization. Article 2. Accumulation of silicites and hydrothermal activity. Bulletin of Moscow Society of Naturalists. Geological Section 71 (3), 31-41 (in Russian) [Цеховский Ю.Г., Муравьев В.И., Музылев Н.Г., Ахметьев М.А. Раннекайнозойское осадконакопление на древних и молодых платформах центральной части Евразии в обстановках растяжения земной коры и пенепленизации рельефа. Статья 2. Накопление силицитов и гидротермальная деятельность // Бюллетень Московского общества испытателей природы. Отдел геологический. 1996. т. 71. Вып. 3. С. 31-41].

Ufimtsev G.F., 1993. The morphostructural significance of listric faults in the Baikal rift. Geotektonika (Geotectonics) (6), 88-93 (in Russian) [Уфимщев Г.Ф. Морфоструктурное значение листрических сбросов в Байкальском рифте // Геотектоника. 1993. № 6. С. 88-93].

Volkova V.S., Kuz'mina O.B., 2005. Flora, vegetation, and climate of the Middle Cenophytic (Paleocene-Eocene) of Siberia: palynological data. Geologiya i Geofizika (Russian Geology and Geophysics) 46 (8), 822-833.

Vorob'eva G.A., Mats V.D., Shimaraeva M.K., 1995. Late Miocene, Pliocene, and Eopleistocene paleoclimates in the Baikal Region. Geologiya i Geofizika (Russian Geology and Geophysics) 38 (8), 82-96 (in Russian) [Воробьёва Г.А., Мац В.Д., Шимараева М.К. Палеоклиматы позднего миоцена, плиоцена и эоплейстоцена // Геология и геофизика. 1995. Т. 38. № 8. С. 82-96].

Zamaraev S.M., Adamenko O.M., Ryazanov G.V., Kul'chitskiy A.A., Adamenko R.S., Vikent'yeva N.M., 1976. Structure and Evolution History of the Baikal Foredeep. Nauka, Moscow, 134 p. (in Russian) [Замараев С.М., Адаменко О.М., Резанов Г.Ф., Кульчицкий А.А., Адаменко Р.С., Викентьева Н.М. Структура и история развития Предбайкальского предгорного прогиба. М.: Наука, 1976. 134 с.].

Zamaraev S.M., Samsonov V.V., 1959. The geological structure and oil-bearing capacities of the Selenga depression. In: Geology and Oil-Bearing Potential of East Siberia. Gostopotekhizdat, Moscow, p. 435-475 (in Russian) [Замараев С.M., Самсонов В.В. Геологическое строение и нефтегазоносность Селенгинской депрессии // Геология и нефтегазоносность Восточной Сибири. М.: Гостопотехиздат, 1959. С. 435-475].

Zanin Yu.N., 1975. Geology of Phosphate-Bearing Weathering Crusts and Related Phosphate Deposits. Nauka, Novosibirsk, 210 p. (in Russian) [Занин Ю.Н. Вещественный состав фосфатоносных кор выветривания и связанных с ними месторождений фосфатов. Новосибирск: Наука, 1975. 210 с.].

Zonenshain L.P., Kaz'min V.G., Kuz'min M.I., 1995. New data on the Baikal history: observations from manned submersibles. Geotektonika (Geotectonics) (3), 46-58 (in Russian) [Зоненшайн Л.П., Казьмин В.Г., Кузьмин М.И. Новые данные по истории Байкала: результаты наблюдений с подводных обитаемых аппаратов // Геотектоника. 1995. № 3. С. 46-58].

Zonenshain L.P., Kaz'min V.G., Kuz'min M.I., Dobretsov N.L., Baranov B.V., Kononov M.K., Mats V.D., Balla Z., Fialkov V.A., Kharchenko V.V., 1993. The geology of the Baikal bottom, studied from "Pisces" submersibles. Doklady AN 330 (1), 84-88 (in Russian) [Зоненшайн Л.П., Казьмин В.Г., Кузьмин М.И., Добрецов Н.Л., Баранов Б.В., Кононов М.К., Мац В.Д., Балла З., Фиалков В.А., Харченко В.В. Геология дна Байкала, изученная с подводных аппаратов "Пайсис" // Доклады АН. 1993. Т. 330. № 1. С. 84-88].

Zorin Y.A., Turutanov E.K., 2005. Plumes and geodynamics of the Baikal rift zone. Geologiya i Geofizika (Russian Geology and Geophysics) 46 (7), 669-682.

Zorin Y.A., Turutanov E.K., Mordvinova V.V., Kozhevnikov V.M., Yanovskaya T.B., Treussov A.V., 2003. The Baikal rift zone: the effect of mantle plumes on older structure. Tectonophysics 371 (1-4), 153-173. http://dx.doi.org/10.1016/ S0040-1951(03)00214-2.

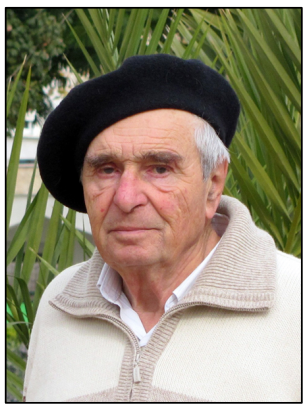

Мац Виктор Давыдович, докт. геол.-мин. наук, профессор

Последнее место работы: Лимнологический институт СО РАН

Домашний адрес: 20101, Кармиель, ул. Шаар Хагай, д. 13, кв. 10, Израиль

\e-mail: matsvic@bezeqint.net

Mats, Victor D., Doctor of Geology and Mineralogy, Professor

Retired from the Institute of Limnology, Siberian Branch of RAS

Home address: 13, Ap. 10, Shaar Hagai street, Karmiel 20101, Israel

$\triangle$ e-mail: matsvic@bezeqint.net 